\title{
Vertical particle flux in the northeast Atlantic Ocean (POMME experiment)
}

\author{
C. Guieu, ${ }^{1}$ M. Roy-Barman, ${ }^{2}$ N. Leblond, ${ }^{1}$ C. Jeandel, ${ }^{3}$ M. Souhaut, ${ }^{3}$ B. Le Cann, ${ }^{4}$ \\ A. Dufour, ${ }^{1}$ and C. Bournot ${ }^{5}$ \\ Received 13 August 2004; revised 14 February 2005; accepted 2 June 2005; published 26 July 2005.
}

[1] In the framework of the Programme Océan Multidisciplinaire Méso Echelle (POMME) experiment, a 1.5 year record (February 2001-June 2002) of downward particle flux at $400 \mathrm{~m}$ and $1000 \mathrm{~m}$ was measured by sediment traps at four moorings located in the northeast Atlantic between $39^{\circ}-43^{\circ} \mathrm{N}$ and $17^{\circ}-19^{\circ} \mathrm{W}$. Thorium- 230 was used to estimate sediment trap efficiency, revealing values ranging from 18.5 to $55 \%$. The lowest trapping efficiency was observed for the trap having experienced the highest currents. Significant interannual variability between 2001 and 2002 was clearly linked to the differences observed in the mixed layer depth. At some sites, particulate organic carbon (POC) export was higher (up to a factor of 1.6) during summer than during the spring event. This could be related to the occurrence of short wind events that deepened the thermocline along with the presence of anticyclonic eddies, yielding an input of new nutrients. The average percentage of POC exported compared to the primary production of organic carbon in the surface waters ranged between 1.3 and $5.0 \%$, with higher export efficiency during the spring. Finally, although the area was shown to present a relatively high mesoscale activity that might impact the geochemistry, POC export was rather homogeneous over the POMME area: $4.9 \pm 1.6 \mathrm{gC} \mathrm{m}^{-2} \mathrm{yr}^{-1}$ were exported below $1000 \mathrm{~m}$ between February 2001 and February 2002. Therefore a large fraction of the new production may be exported through convection and mode water circulation rather than by particle settling.

Citation: Guieu, C., M. Roy-Barman, N. Leblond, C. Jeandel, M. Souhaut, B. Le Cann, A. Dufour, and C. Bournot (2005), Vertical particle flux in the northeast Atlantic Ocean (POMME experiment), J. Geophys. Res., 110, C07S18, doi:10.1029/2004JC002672.

\section{Introduction}

[2] The aim of the POMME Experiment was to study the formation and transport of the mode water in the Eastern North Atlantic and of its impact on carbon sequestration in the ocean, with a special emphasis on the role of the mesoscale circulation [Mémery et al., 2005]. In the NE Atlantic around $42^{\circ} \mathrm{N}$, there is a marked discontinuity of the winter mixed layer depth between the subtropical waters: the deep winter mixing north of this discontinuity is

\footnotetext{
${ }^{1}$ Laboratoire d'Océanographie de Villefranche, Centre National de la Recherche Scientifique, Villefranche-sur-mer, France.

${ }^{2}$ Laboratoire des Sciences du Climat et de l'Environnement/Institut Pierre-Simon Laplace, Centre National de la Recherche Scientifique, Gifsur-Yvette, France.

${ }^{3}$ Laboratoire d'Etudes en Géophysique et Océanographie Spatiales, Centre National de la Recherche Scientifique/Centre National d'Etudes Spatiales/Institut de Recherche pour le Développment/Université Paul Sabatier, Observatoire Midi-Pyrénées, Toulouse, France.

${ }^{4}$ Laboratoire de Physique des Océans, UMR 6523, Centre National de la Recherche Scientifique/Institut Français de Recherche pour l'Exploitation de la Mer/Université de Bretagne Occidentale, Brest, France.

${ }^{5}$ Institut National des Sciences de l'Univers/Centre National de la Recherche Scientifique Division Technique, Technopôle Brest-Iroise, Plouzané, France.
}

Copyright 2005 by the American Geophysical Union. 0148-0227/05/2004JC002672\$09.00 followed by the southward subduction of ventilated mode water [Paillet and Arhan, 1996; Reverdin et al., 2005]. When atmospheric $\mathrm{CO}_{2}$ dissolves in the ocean surface and becomes dissolved inorganic carbon (DIC), it can be isolated from the atmosphere if it is transported at depth by the mode waters. In the surface water, part of the DIC is converted to organic carbon by photosynthesis. This organic carbon itself can be isolated from the atmosphere either as dissolved organic carbon (DOC) transported in the mode water or as particulate organic carbon (POC) that sinks through the water column. Part of this POC is remineralized in the mode water. It is therefore essential to measure the POC flux in order to balance the carbon budget.

[3] Several studies suggest that mesoscale activity play a significant role in vertical transport and in the supply of nutrients to the euphotic zone and thus in the control of photosynthesis. The role of eddies in pumping nutrients to the surface has recently been identified as the dominant nutrient supply mechanism in the Sargasso Sea [McGillicuddy et al., 1998] while substantial nutrient vertical transport can occur at smaller scales from eddy instabilities [Mahadevan and Archer, 2000; Lévy et al., 2001]. The impact of these mesoscale features on the export of particulate carbon in the mesopelagic zone is less well constrained but the spatial and temporal variability of the fluxes that it may produce has to be quantified [Neuer et al., 1997; Newton et al., 1994]. 
Table 1. Location, Date, and Collection Time for the Four Moorings

\begin{tabular}{|c|c|c|c|c|}
\hline & Mooring NE & Mooring SE & Mooring NW & Mooring SW \\
\hline \multicolumn{5}{|c|}{ First Deployment } \\
\hline Mooring date & 10 Feb 2001 & 12 Feb 2001 & 16 Feb 2001 & 18 Feb 2001 \\
\hline Position & $43^{\circ} 32.867 \mathrm{~N}, 17^{\circ} 20.868 \mathrm{~W}$ & $39^{\circ} 30.229 \mathrm{~N}, 17^{\circ} 15.182 \mathrm{~W}$ & $42^{\circ} 59.760 \mathrm{~N}, 19^{\circ} 04.402 \mathrm{~W}$ & $39^{\circ} 34.85 \mathrm{~N}, 18^{\circ} 51.23 \mathrm{~W}$ \\
\hline Sampling period & 14 Feb-25 Aug 2001 & 14 Feb-25 Aug 2001 & 20 Feb-25 Aug 2001 & 20 Feb-25 Aug 2001 \\
\hline Sampling duration, days & 8 & 8 & 8 & 8 \\
\hline \multicolumn{5}{|c|}{ Second Deployment } \\
\hline Mooring date & 31 Aug 2001 & 29 Aug 2001 & 7 Sep 2001 & \\
\hline Position & $43^{\circ} 32.498 \mathrm{~N}, 17^{\circ} 20.110 \mathrm{~W}$ & $39^{\circ} 31.683 \mathrm{~N}, 17^{\circ} 15.200 \mathrm{~W}$ & $43^{\circ} 00.514 \mathrm{~N}, 19^{\circ} 03.99 \mathrm{~W}$ & \\
\hline Sampling period & 9 Sep 2001-24 Jun 2002 & 9 Sep 2001-24 Jun 2002 & 9 Sep 2001-24 Jun 2002 & \\
\hline Sampling duration, days & 12 & 12 & 12 & \\
\hline
\end{tabular}

[4] The particulate flux was sampled almost continuously during the POMME experiment using 4 instrumented moorings equipped with traps at $400 \mathrm{~m}$ and $1000 \mathrm{~m}$ depths that correspond to upper and mid mesopelagic layer depths. To constrain the role of mesoscale activity on export production, the deployment of these moorings formed a quadrangle the size $(200 \times 400 \mathrm{~km})$ that was larger than mesoscale eddies ( $\sim 100 \mathrm{~km}$ in diameter) The aim of the present paper is to give the main results that were obtained from the deployment of the fixed sediment traps. The complementary results obtained from the deployment of the drifting sediment traps can be found in a companion paper [Goutx et al., 2005].

[5] We will discuss the spatiotemporal variations of the particle flux over the 16 month collection period and the geochemistry of these particles mainly during the first deployment (February-August 2001). This period corresponds to the intense field work that took place in the POMME area with three cruises, each with two legs in 2001.

[6] Particulate Carbon and a variety of biogenic and lithogenic tracers $(\mathrm{Ca}, \mathrm{Ba}, \mathrm{Al}, \mathrm{Fe})$ were fully investigated to identify the particulate matter chemistry and to understand the relationship of export production to new production in the POMME quadrangle, an oceanic area submitted to intense mesoscale circulation. It is well established that in the upper and midmesopelagic zone, sediment traps often undercollect the flux of sinking particles. The trapping efficiency can be estimated by measuring the flux of in situ produced nuclides such as ${ }^{230} \mathrm{Th}$. The trapping efficiency is obtained by comparing the ${ }^{230} \mathrm{Th}$ flux collected by the trap with the ${ }^{230} \mathrm{Th}$ produced in the water column overlying the trap. Therefore a particular effort was made to analyze Th isotopes in order to properly constrain the particle flux.

\section{Methodology}

\subsection{In the Field}

[7] Settling particles were collected with a multisample conical sediment traps (PPS5) with a collection surface of $1 \mathrm{~m}^{2}$, moored at 400 and $1000 \mathrm{~m}$. Sediment traps were deployed over two periods: from February 2001 to August 2001 ("first deployment period"; sampling interval $=8$ days) and from August 2001 to June 2002 ("second deployment period"; sampling interval = 12 days). The position of the four moorings can be found in Table 1 and Figure 1; they will be named hereafter northwest (NW), northeast (NE), southwest (SW), and southeast (SE). Sam- pling procedures were done following the protocols established by JGOFS and can be found at http://www.obs-vlfr.fr/ LOV/Pieges. The solution in the collection cups consisted of a $5 \%$ buffered formaldehyde prepared with in situ seawater collected by Niskin sampling bottles. Deep ocean, long-term deployments with tracer studies was proved to experience solubilization of particulate matter which degree depends on the type of poison used to preserve the samples; that may affect, for example, POC fluxes (see section 4). After recovery of the traps, the samples were stored at cold $\left(4^{\circ} \mathrm{C}\right)$ and dark inside a refrigerator. A total of 324 samples were collected (only $4 \%$ of the samples were not successful). All moorings were equipped with one inclinometer at $400 \mathrm{~m}$ and current meters (Aanderaa RCM7), which were located at 400 and $1000 \mathrm{~m}$. Velocities are available for all the series except for the second deployment period at NW site; the angles are available for the whole series except for the first deployment period at NE site.

\subsection{In the Laboratories}

[8] Back in the laboratory in Villefranche-sur-mer, swimmers were identified and carefully removed from the samples by means of Teflon coated tweezers under a stereomicroscope (LEICA WILD MZ8). During this step, any visible material attached to the swimmers was carefully removed as best as possible, to avoid at maximum biasing the particulate flux. On average, 850 swimmers cup $^{-1}$ were removed for samples collected at $400 \mathrm{~m}$ and 270 swimmers cup $^{-1}$ were removed for samples collected at $1000 \mathrm{~m}$. After the swimmers being removed, microphotographs of each sample were taken (they are available at http://www.obsvlfr.fr/LOV/Pieges).

[9] The whole sample was then rinsed three times with $50 \mathrm{~mL}$ of ultrapure (MilliQ) water in order to remove salt and then freeze-dried. Mass fluxes (Figure 2) were measured by weighing the whole freeze-dried sample five times. The accuracy of the weighing (and thus of the flux) was $1 \%$ over the whole data series. Total concentration of carbon (TC) and nitrogen were measured in triplicate with a LECO900 elemental analyzer (CHN) on aliquots of the desiccated samples $(3-4 \mathrm{mg})$. Acid digestion was performed on aliquots of the desiccated samples. The acid digestions of the 324 sediment trap samples was shared between LOV and LEGOS. The acid-digested samples were used to analyze Al, Fe, Ca by ICP/AES Jobin Yvon (JY 138 "Ultrace") at Villefranche-sur-mer, Phosphorus by spectrophotometry [Murphy and Riley, 1962] at Villefranche-surmer (SECOMAN ANTHELIC Data) and heavy elements 


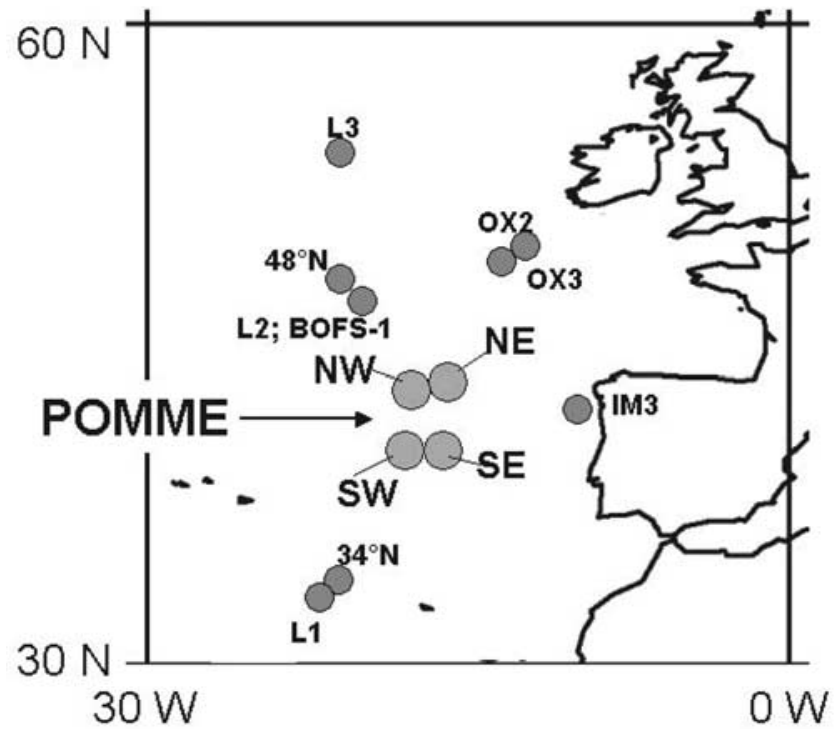

Figure 1. Location of the four moorings in the Programme Océan Multidisciplinaire Méso Echelle (POMME) area along with the location of the previous studies between $30^{\circ}-60^{\circ} \mathrm{N}$ and $0^{\circ}-30^{\circ} \mathrm{W}$ (see Table 3 for details).

(Ba, ${ }^{232} \mathrm{Th}$ and other trace metals) using the ICP/MS Perkin Elmer Elan 6000 at Toulouse. The procedure was validated by an intercomparison exercise (see http://www.lodyc.jussieu.fr/ POMME) that showed that the analyses of sediment trap samples and certified sediments acid digested at LOV or LEGOS agreed within an average error of $4-5 \%$ for heavy and light elements. For certified samples (BCSS1: marine sediment from National Research Council Canada and GBW07313: marine sediment from National Research Center for Certified Reference Materials) results were consistent with the certified data. The average blank values estimated on 30 solutions representative of the experimental acid digestion/dilution procedure were well below the level of the POMME samples. For example, the Ba detection limit (i.e., three standard deviations of the blanks) was $18 \mathrm{ng} \mathrm{g}^{-1}$ but the average signal was $400 \mathrm{ng} \mathrm{g}^{-1}$. The ${ }^{232} \mathrm{Th}$ detection limit was $10 \mathrm{pg} \mathrm{g}^{-1}$ but the average signal was larger $2 \mathrm{ng} \mathrm{g}^{-1}$.

\subsection{Thorium-230 and Thorium-232 by TIMS}

[10] After complete dissolution of the samples, an aliquot of the solution was dedicated to Th analysis. ${ }^{229} \mathrm{Th}$ spike was added to this aliquot. After isotopic equilibration, the Th was purified by ion exchange chemistry [Roy-Barman et al., 1996]. Typical procedural blanks (around $20 \mathrm{pg}$ of ${ }^{232} \mathrm{Th}$ and $0.1 \mathrm{fg}$ of ${ }^{230} \mathrm{Th}$ ) represent typically less than $1-$ $2 \%$ of the Th in the samples. For the SW400 and SW1000 traps and the first period of the NE 400 trap, the purified Th was loaded on a single Re filament with a colloidal graphite matrix and analyzed by TIMS on a Finnigan Mat 262 mass spectrometer equipped with an ion counting system as described by Roy-Barman et al. [2002]. The agreement between the measured ${ }^{230} \mathrm{Th} /{ }^{232} \mathrm{Th}$ ratio and the recommended value [Banner et al., 1990] of a Th standard indicates that the accuracy of the TIMS measurement is typically better than $2 \%$. The remaining samples (the second period of the NE 400 trap and the two periods of the NE1000, SE400, SE1000, NW400 and NW1000 traps) were analyzed in Toulouse by MC-ICP-MS on a Neptune (Finnigan) equipped with an RPQ system. The detailed procedure will be published elsewhere (M. Roy-Barman et al., The influence of particle composition on Thorium isotope scavenging in the NE Atlantic Ocean, submitted to Earth and Planetary Science Letters, 2005, hereinafter referred to as Roy-Barman, submitted manuscript, 2005). In short, samples were injected in the plasma in $2 \%$ nitric acid solution. The different masses were measured in a dynamic mode on a single ion counting system. Mass fractionation was corrected by bracketing samples with standard measurements.

\subsection{Evaluation of the Composition of the Sinking Material}

[11] The material collected by the traps is made of fecal pellets, marine snow and individual foraminifera tests in variable proportions. The elemental analysis were used to calculate the 4 main fractions of the collected material: carbonates, organic matter, opal, lithogenic fraction. The carbonate fraction was determined from particulate $\mathrm{Ca}$ concentrations as follows: $\% \mathrm{CaCO}_{3}=5 / 2 \times(\% \mathrm{Ca})$. Particulate inorganic carbon (PIC) was deduced from the carbonate fraction assuming that $\% \mathrm{PIC}=\% \mathrm{CaCO}_{3} / 8.33$. This approach was chosen rather than measurement after decarbonatation because it was shown in a preliminary phase (N. Leblond, unpublished manuscript, 2003) (available at http://www.obs-vlfr.fr/LOV/Pieges) of the POMME experiment that this indirect method was more accurate. The particulate organic carbon (POC) was then determined by subtracting PIC from TC. The organic matter fraction was calculated as $2 \times(\%$ POC). Biogenic (BSi) and lithogenic (LSi) silica were measured in Laboratoire d'Océanographie et de Biogéochimie (Marseille) and data can be found in Mosseri et al. [2005]. By using the BSi data, the opal $\left(\mathrm{SiO}_{2}\right.$, $\mathrm{nH}_{2} \mathrm{O}$ ) fraction was determined (assuming that $n=0.4$ [Mortlock and Froelich, 1989]). The lithogenic fraction was estimated from the Aluminum concentrations assuming that the average $\mathrm{Al}$ concentration in the upper crust is $7.74 \%$ [Wedepohl, 1995].

\section{Results}

[12] All the data discussed are available at http://www. lodyc.jussieu.fr/POMME.

\section{1. ${ }^{230} \mathrm{Th}_{\text {ex }}$ Flux}

[13] A detailed report and discussion of the thorium data will be presented elsewhere (Roy-Barman et al., submitted manuscript, 2005). Here, we focus on the average ${ }^{230} \mathrm{Th}_{e x}$ flux collected at the NE and SW sites in order to evaluate the sediment trap efficiency. The ${ }^{230} \mathrm{Th}$ produced by the in situ decay of ${ }^{234} \mathrm{U}$ in seawater and scavenged on particles $\left({ }^{230} \mathrm{Th}_{e x}\right)$ is calculated by subtracting the lithogenic ${ }^{230} \mathrm{Th}$ component to the total ${ }^{230} \mathrm{Th}$ :

$$
{ }^{230} \mathrm{Th}_{e x}={ }^{230} \mathrm{Th}_{\text {measured }}-{ }^{232} \mathrm{Th}_{\text {measured }} \times\left({ }^{230} \mathrm{Th} /{ }^{232} \mathrm{Th}\right)_{\text {litho }},
$$

with $\left({ }^{230} \mathrm{Th} /{ }^{232} \mathrm{Th}\right)_{\text {litho }}=4.4 \times 10^{-6}$ based on a mean composition of the continental crust [Andersson et al., 1995]. For simplicity, we report the average ${ }^{230} \mathrm{Th}_{e x}$ 

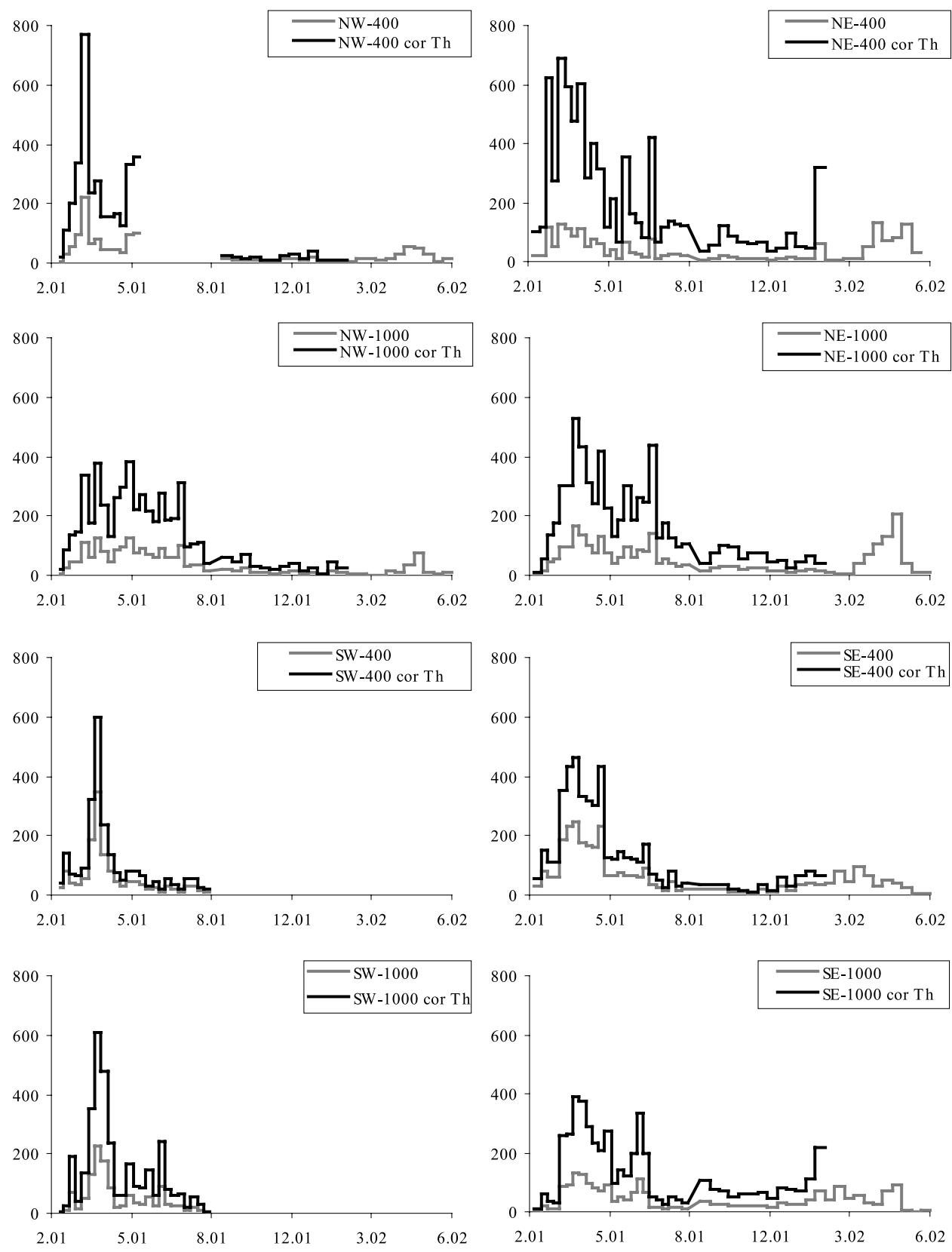

Figure 2. Mass flux over the POMME quadrangle from February 2001 to June 2002 at the four moorings. Units are $\mathrm{mg} \mathrm{m}^{-2} \mathrm{~d}^{-1}$. Both data (bulk and corrected from ${ }^{230} \mathrm{Th}$ calibration) are presented.

collected by the trap as a fraction of the in situ production of ${ }^{230} \mathrm{Th}$ above the trap $\left(630 \mathrm{~m}^{-2} \mathrm{~d}^{-1}\right.$ at $400 \mathrm{~m}$ and $1575 \mathrm{~m}^{-2} \mathrm{~d}^{-1}$ at $\left.1000 \mathrm{~m}\right)$. For the NE traps a full year (February 2001-2002) was analyzed at each depth. At $1000 \mathrm{~m}$, the average ${ }^{230} \mathrm{Th}_{\mathrm{ex}}$ is $505 \mathrm{fg} \mathrm{m}^{-2} \mathrm{~d}^{-1}$ meaning that $32 \%$ of the annual production was collected by the trap. At $400 \mathrm{~m}$, the average ${ }^{230} \mathrm{Th}_{\mathrm{ex}}$ is $114 \mathrm{fg} \mathrm{m}^{-2} \mathrm{~d}^{-1}$ meaning that only $18 \%$ of the production was collected. At SE1000 and NW1000, a full year was also analyzed. The collected ${ }^{230} \mathrm{Th}_{\text {ex }}$ flux represents 33\% for NW1000 and 34\% for SE1000. For the other traps all the data were not available. The SW traps only collected from late winter to summer 2001. At $400 \mathrm{~m}$, the average ${ }^{230} \mathrm{Th}_{\mathrm{ex}}$ is $367 \mathrm{fg} \mathrm{m}^{-2} \mathrm{~d}^{-1}(58 \%$ of the production at $400 \mathrm{~m})$. At $1000 \mathrm{~m}$, the average ${ }^{230} \mathrm{Th}_{\mathrm{ex}}$ is $576 \mathrm{fg} \mathrm{m}^{-2} \mathrm{~d}^{-1}(37 \%$ of the production at $1000 \mathrm{~m})$. For
NW400, the average ${ }^{230} \mathrm{Th}_{\text {ex }}$ flux represents $20 \%$ of the production but no samples were collected from June to early September. For SE400, the average ${ }^{230} \mathrm{Th}_{\mathrm{ex}}$ flux represents $49 \%$ of the production (but this average excludes the September to December 2001 period for which the ${ }^{230} \mathrm{Th}_{x s}$ concentrations were not measured).

\subsection{Mass Flux and POC Flux}

[14] Fluxes were measured continuously from February 2001 to June 2002, except for a mooring change between 25 August and 9 September 2001. The NW $400 \mathrm{~m}$ trap also did not collect between June and August 2001. For the SW trap, the flux was only measured from February to August 2001. For NW (1000 m), NE and SE, these data cover two spring bloom periods. 
Table 2. Comparison of the Mass Fluxes Measured From February to June in 2001 and $2002^{a}$

\begin{tabular}{|c|c|c|c|c|}
\hline & SW & SE & NW & $\mathrm{NE}$ \\
\hline \multicolumn{5}{|c|}{$400 \mathrm{~m}$} \\
\hline \multicolumn{5}{|l|}{2001} \\
\hline Highest flux & 805 & 445 & 789 & 686 \\
\hline Date of highest flux & 3-11 Apr & 3-11 Apr & 18-26 Mar & $18-26 \mathrm{Mar}$ \\
\hline Mean flux & 179 & 223 & 254 & 346 \\
\hline \multicolumn{5}{|l|}{2002} \\
\hline Highest flux & no data & 173 & 186 & 703 \\
\hline Date of highest flux & no data & $20 \mathrm{Mar}-1 \mathrm{Apr}$ & 25 Apr-7 May & 13-25 Apr \\
\hline Mean flux & no data & 81 & 78 & 290 \\
\hline \multicolumn{5}{|c|}{$1000 \mathrm{~m}$} \\
\hline \multicolumn{5}{|l|}{2001} \\
\hline Highest flux & 818 & 388 & 376 & 525 \\
\hline Date of highest flux & 3-11 Apr & 3-11 Apr & 3-11 April & 3-11 Apr \\
\hline Mean flux & 235 & 187 & 217 & 246 \\
\hline \multicolumn{5}{|l|}{2002} \\
\hline Highest flux & no data & 271 & 224 & 650 \\
\hline Date of highest flux & no data & 7-19 May & 7-19 May & 7-19 Мay \\
\hline Mean flux & no data & 121 & 47 & 181 \\
\hline
\end{tabular}

[15] The mass fluxes were highly variable in time. In 2001, the highest mass fluxes at $400 \mathrm{~m}$ were collected between 18 and 26 March at sites NW and NE and between 3 and 11 April at sites SW and SE. These highest fluxes range from $445 \mathrm{mg} \mathrm{m}^{-2} \mathrm{~d}^{-1}$ (SE site) to $805 \mathrm{mg} \mathrm{m}^{-2} \mathrm{~d}^{-1}$ (SW site). At $1000 \mathrm{~m}$ the highest fluxes were recorded between 3 and 11 April at all the sites. They range from $388 \mathrm{mg} \mathrm{m}^{-2} \mathrm{~d}^{-1}$ (SE site) to $818 \mathrm{mg} \mathrm{m}^{-2} \mathrm{~d}^{-1}$ (SW site) (Table 2). The lowest fluxes were recorded from summer to winter.

[16] Finally, a mean mass flux over the POMME quadrangle has been calculated over a 1 year period (February 20012002): $51 \pm 11 \mathrm{~g} \mathrm{~m}^{-2} \mathrm{yr}^{-1}$ at $400 \mathrm{~m}$ and $53 \pm 13 \mathrm{~g} \mathrm{~m}^{-2} \mathrm{yr}^{-1}$ at $1000 \mathrm{~m}$. Results are reported in Table 3. However there is an important interannual variability. In 2002, the spring bloom occurred approximately 1 month later than in 2001 and the quantity of material exported during the 2002 bloom was about half of the quantity recorded during the 2001 bloom (Figure 3, Table 2).

[17] Time series variability of POC fluxes at 400 and $1000 \mathrm{~m}$ between February 2001 and February 2002 is reported on Figure 4. At the south sites, POC fluxes have the same pattern but with a 1 month lag between the two maxima which occurred in mid-April and in mid-May respectively for the SW and SE sites. This interesting feature could not be observed with the mass flux alone because the POC flux is not perfectly correlated to the mass flux. It should be noted that two POC export periods occurred, in particular for the northern sites at $1000 \mathrm{~m}$; the data show that during the second period (June-August) the export can be even higher than during the "spring bloom" (Table 4).

[18] Despite these deviations, the relation between POC mass and total mass flux was examined at both depths between February 2001 and June 2002. At $400 \mathrm{~m}$, these data are linearly related with a $r^{2}=0.81$ (figure not shown). In the mean, POC was $9.5 \%$ of the mass flux but point by point they ranged between 2 and $26 \%$. At $1000 \mathrm{~m}$, the plot is more scattered $\left(r^{2}=0.67\right)$. In the mean, POC was $8.7 \%$ of the mass flux but point by point they ranged between 5 and $35 \%$. This is of the same order of magnitude as the proportion found for the entire data set reported in Table 3 in which $\sim 8 \%$ of the mass flux is composed of POC.

[19] On average over the POMME zone, between February 2001 and February 2002, the POC flux was $14.2 \pm 2.7 \mathrm{mg}$ $\mathrm{m}^{-2} \mathrm{~d}^{-1}$ at $400 \mathrm{~m}$ (i.e., $5.1 \pm 1.0 \mathrm{gC} \mathrm{m}^{-2} \mathrm{yr}^{-1}$ ) and $13.5 \pm$ $4.5 \mathrm{mgC} \mathrm{m}^{-2} \mathrm{~J}^{-1}$ at $1000 \mathrm{~m}$ (i.e., $4.9 \pm 1.6 \mathrm{gC} \mathrm{m}^{-2} \mathrm{yr}^{-1}$ ).

\subsection{Composition of the Sinking Material}

[20] Over the whole sample series, the carbonates made up most of the mass flux (Figure 5). They account for 57\% of the total collected material. The organic matter accounted for $20 \%$, the opal for $15 \%$ and the lithogenic fraction for only $4 \%$. The proportion of carbonate was the highest for the NE site at $400 \mathrm{~m}(68 \%)$ and at the same site, the proportion of opal was the lowest (only 5\%).

[21] The highest lithogenic fraction was found for the west sites: the proportions reaching around $20 \%$ of the total flux for the NW site at $1000 \mathrm{~m}$ during the low-flux period at the end of the winter. Lithogenic fraction was particularly low for the NE site $(1 \%$ at $400 \mathrm{~m}$ and $3 \%$ at $1000 \mathrm{~m})$ reflecting particularly low inputs from the atmosphere and lateral input, although this site is the closest to the Iberian shelf.

[22] For all sites, the proportion of organic matter in the sinking particles was minimum (around 16\%) up to midApril and then increased after the period of maximum flux and remained constant during the summer with an average proportion of $26 \%$. Biogenic silicate represent a small fraction of the material collected. On average $15 \%$ of the sinking material was biogenic silica, the proportion of opal being particularly low at the NE 400 trap (5\%).

\subsection{Biogenic Ba}

[23] It has been suggested that the biogenic $\mathrm{Ba}$ (noted $\mathrm{Ba}_{x s}$ in this work) could be used to reconstruct surface export production when its average flux is measured in moored sediment trap at a given site [Francois et al., 1995], although the biological mechanism yielding Ba formation is still not understood [Bishop, 1988; Dehairs et al., 1997; Jeandel et al., 2000]. In the framework of POMME, total $\mathrm{Ba}$ was systematically analyzed in the trap samples. Our 


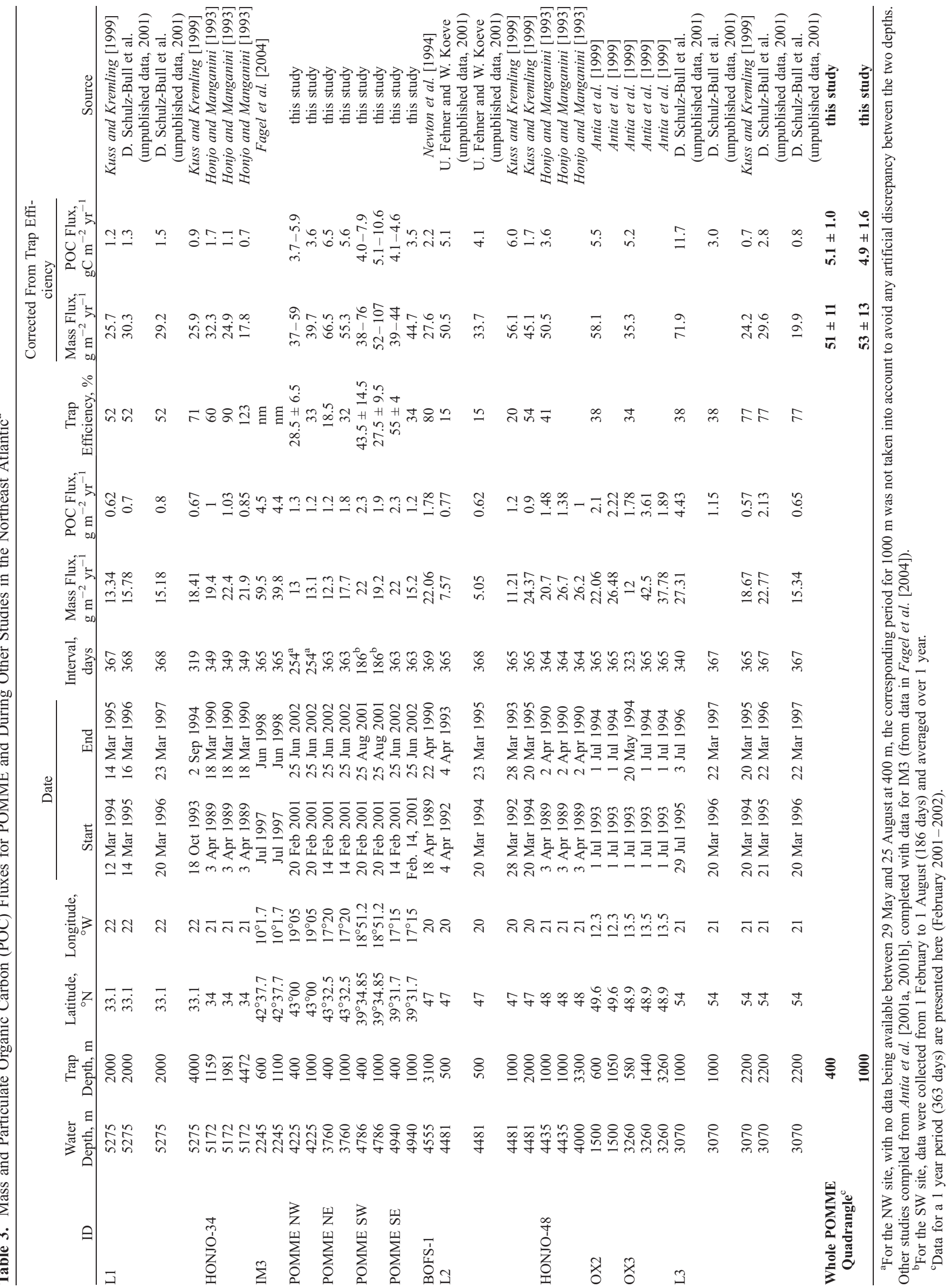



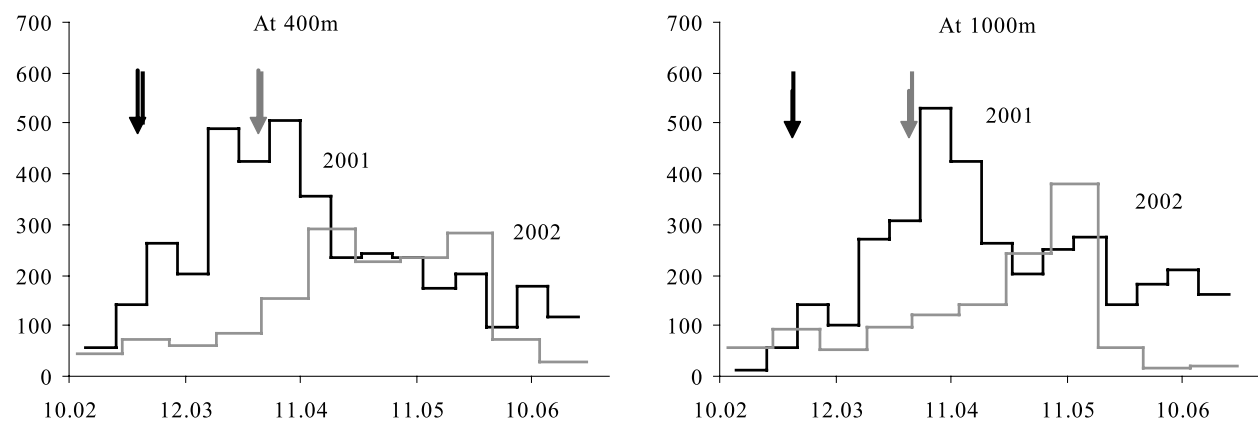

Figure 3. Comparison of the mass fluxes between February and June in 2001 and 2002: average at (left) $400 \mathrm{~m}$ and (right) $1000 \mathrm{~m}$. The arrows indicate the maximum mixed layer depth (MLD) and the beginning of the stratification (from Lévy et al. [2005b]).

results have the potential to test the empirical relationship between the biogenic $\mathrm{Ba}$ and the exported POC proposed by Francois et al. [1995].

[24] Excess $\mathrm{Ba}\left(\mathrm{Ba}_{x s}\right)$, often considered as biogenic $\mathrm{Ba}$, was calculated as the bulk $\mathrm{Ba}$ content corrected for the terrigeneous $\mathrm{Ba}$ contribution. This excess phase is mainly due to the presence of barite crystals, but can also reflect contributions of authigenic $\mathrm{Ba}$ in celestite, calcium carbonate and some organic phases [Eagle et al., 2003, and references therein]. Terrigeneous $\mathrm{Ba}$ is estimated using a reference crustal $\mathrm{Ba} /{ }^{232} \mathrm{Th}$ ratio of 51.4 [Taylor and McLennan, 1985].

[25] Total $\mathrm{Ba}$ and ${ }^{232} \mathrm{Th}$ contents of individual cup samples, expressed in $10^{-6} \mathrm{~g} \mathrm{~g}^{-1}$ of freeze-dried samples vary by a factor of 100 and 25 respectively $(22<\mathrm{Ba}<2525$ and $0.05<{ }^{232} \mathrm{Th}<1.2$ (data can be found at http:// www.obs-vlfr.fr/LOV/Pieges).

\subsection{Currents and Inclination: Relation to Mesoscale Activity}

[26] The current speed, recorded by current meters at $400 \mathrm{~m}$ and $1000 \mathrm{~m}$, can help the sediment trap interpretation. The mean horizontal current speed and the percentage of current speed higher than $15 \mathrm{~cm} \mathrm{~s}^{-1}$ were calculated over each cup collection period. The data are presented in Figure 6 .

[27] As expected the current speed is higher at $400 \mathrm{~m}$ than at $1000 \mathrm{~m}$. Horizontal speed often exceeded the $15 \mathrm{~cm} \mathrm{~s}^{-1}$ threshold above which currents are known to significantly affect the collection of the settling particles [Baker et al., 1988; Knauer and Asper, 1989]. The NE 400 trap experienced by far the highest current speeds during the whole deployment: instantaneous speeds as high as $48 \mathrm{~cm} \mathrm{~s}^{-1}$ were recorded in NE 400 and current speeds were high from February 2001 to December $2001\left(\right.$ mean $\left.=17 \mathrm{~cm} \mathrm{~s}^{-1}\right)$. These quite high dynamic features are connected to the influence of the anticyclonic eddy A1 that was close to this mooring during that period [Le Cann et al., 2005] (Figures 7 and 11). The NE 1000 trap is also the most affected by the currents among the deep traps, indicating that the A1 eddy dynamical influence is reaching that depth. At the NW site, the environment around the NW 400 trap was quite dynamic by mid-April (maximum velocity during this 1 month period: $36 \mathrm{~cm} \mathrm{~s}^{-1}$ ), also related to the proximity of A1. It also corresponds to the period of highest velocity for the NW1000 trap. These features can be interpreted in terms of eddy dynamics. The analysis of A1 (J.-C. Gascard et al., manuscript in preparation, 2005) showed that its dynamical influence at $400 \mathrm{~m}$ and $1000 \mathrm{~m}$ depth was reaching $\sim 80 \mathrm{~km}$ at least from its center. Its radial profile of azimuthal velocities exhibited a double maximum $\left(\sim 20-40 \mathrm{~cm} \mathrm{~s}^{-1}\right.$ at $400 \mathrm{~m}$ depth, $\sim 10-20 \mathrm{~cm} \mathrm{~s}^{-1}$ at $1000 \mathrm{~m}$ depth) at radii of $\sim 20 \mathrm{~km}$ and $\sim 50 \mathrm{~km}$. A1 was coming from the east (Figure 7) when NE mooring was deployed in February 2001, at $\sim 10-20 \mathrm{~km}$ from A1 center (see also Figure 11). A1 then moved westward, to influence the NW mooring in April (minimum distance from center $\sim 50 \mathrm{~km}$ ). It then took an eastward trajectory, to approach the NE mooring again, after midMay, with a minimum distance between the mooring and eddy center of $\sim 10-20 \mathrm{~km}$ in August 2001. A1 then moved northwestward and finally southwestward, away from the NE mooring. Although we did not track A1 after September 2001, it is plausible that A1 influenced NW mooring after that period (Figure 6). Inspection of the dynamical behavior of the NE and NW sediment trap moorings shows that nearly all the fluctuations in depth and inclination of the traps may be attributed to the influence of A1. Sediment trap depth (at both $400 \mathrm{~m}$ and $1000 \mathrm{~m}$ depths) increased by as much as $\sim 60-80 \mathrm{~m}$ under this influence. These instrument depth increases correspond to trap inclination variations of order $\sim 2^{\circ}-3^{\circ}$.

[28] At the SW and SE sites, the current speeds are generally lower than for the northern sites. During 2001 there was almost no record of current speed higher than $15 \mathrm{~cm} \mathrm{~s}^{-1}$ at the $\mathrm{SW}$ site. SE mooring was under the influence of the weaker anticyclonic eddy A31 (Figure 7) in May-June 2001, with current speeds $\sim 10-15 \mathrm{~cm} \mathrm{~s}^{-1}$ at $400 \mathrm{~m}$ and less than $10 \mathrm{~cm} \mathrm{~s}^{-1}$ at $1000 \mathrm{~m}$. This induced trap depth increases of $\sim 10 \mathrm{~m}$, and inclinations of $\sim 0.5^{\circ}$ only. Anticyclone A2 influenced SW mooring from March to early May 2001, with current speed episodes of $\sim 10-20 \mathrm{~cm} \mathrm{~s}^{-1}$ at $400 \mathrm{~m}$ and $1000 \mathrm{~m}$ depths. These events induced $\sim 30-40 \mathrm{~m}$ depth variations and $\sim 1.5^{\circ}$ inclination at maximum. From hydrological measurements, A2 was seen to be of meddy (Mediterranean eddy) type, with a significant surface reaching expression, which suggested that it was possibly a "northern meddy" [Paillet et al., 2002]. Observed inclinations and depth variations were checked against results from a numerical program to compute mooring dynamics [Girardot, 2000]. For current profiles estimated for maximum values observed at NE mooring, we obtained 

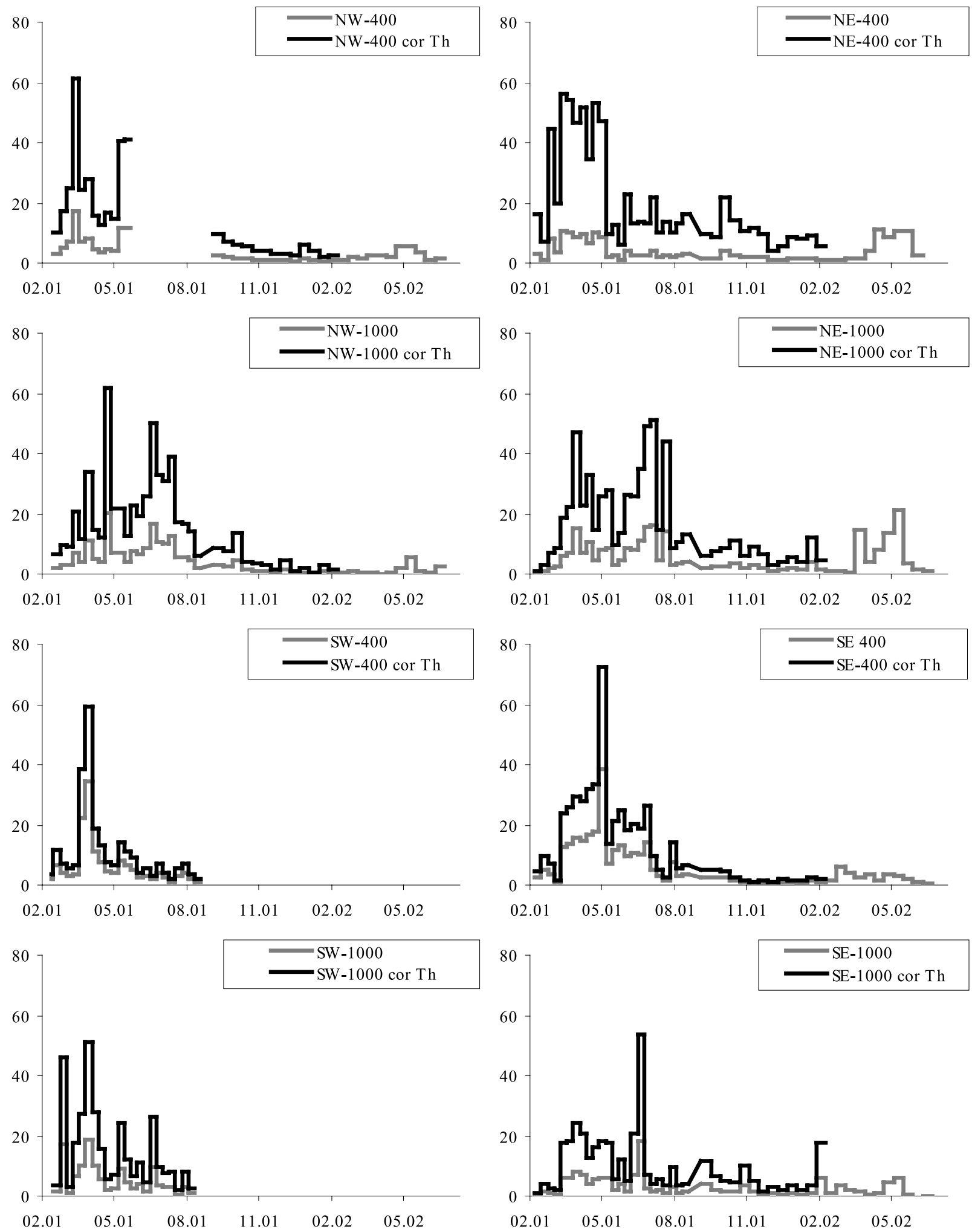

Figure 4. Particulate organic carbon (POC) export over the whole collection period (February 2001June 2002) for the four moorings. Units are $\mathrm{mg} \mathrm{m}^{-2} \mathrm{~d}^{-1}$. Both data (bulk and corrected from ${ }^{230} \mathrm{Th}$ calibration) are presented. 
Table 4. Comparison of POC Export Between 14 February-13 May (88 Days) and 13 May-25 August $(104 \text { Days })^{\mathrm{a}}$

\begin{tabular}{lccc}
\hline & $\begin{array}{c}\text { Spring: } 14 \text { Feb-13 May } \\
\text { (88 Days) }\end{array}$ & $\begin{array}{c}\text { Summer: 13 May-25 Aug } \\
\text { (104 Days) }\end{array}$ & $\begin{array}{c}\text { \% Exported During Summer Compared } \\
\text { to Export During Spring }\end{array}$ \\
\hline SE 400 & 2.1 & 1.4 & 70 \\
SE 1000 & 1.1 & 1.2 & 110 \\
NW 400 & 1.8 & no data & 152 \\
NW 1000 & 1.6 & 2.5 & 41 \\
NE 400 & 3.5 & 1.4 & 162 \\
NE 1000 & 1.6 & 2.6 & 45 \\
SW 400 & 1.9 & 0.8 & 60 \\
SW 1000 & 2.2 & 1.3 & \\
\hline
\end{tabular}

${ }^{\mathrm{a}} \mathrm{POC}$ export is in $\mathrm{g} \mathrm{m}^{-2}$.
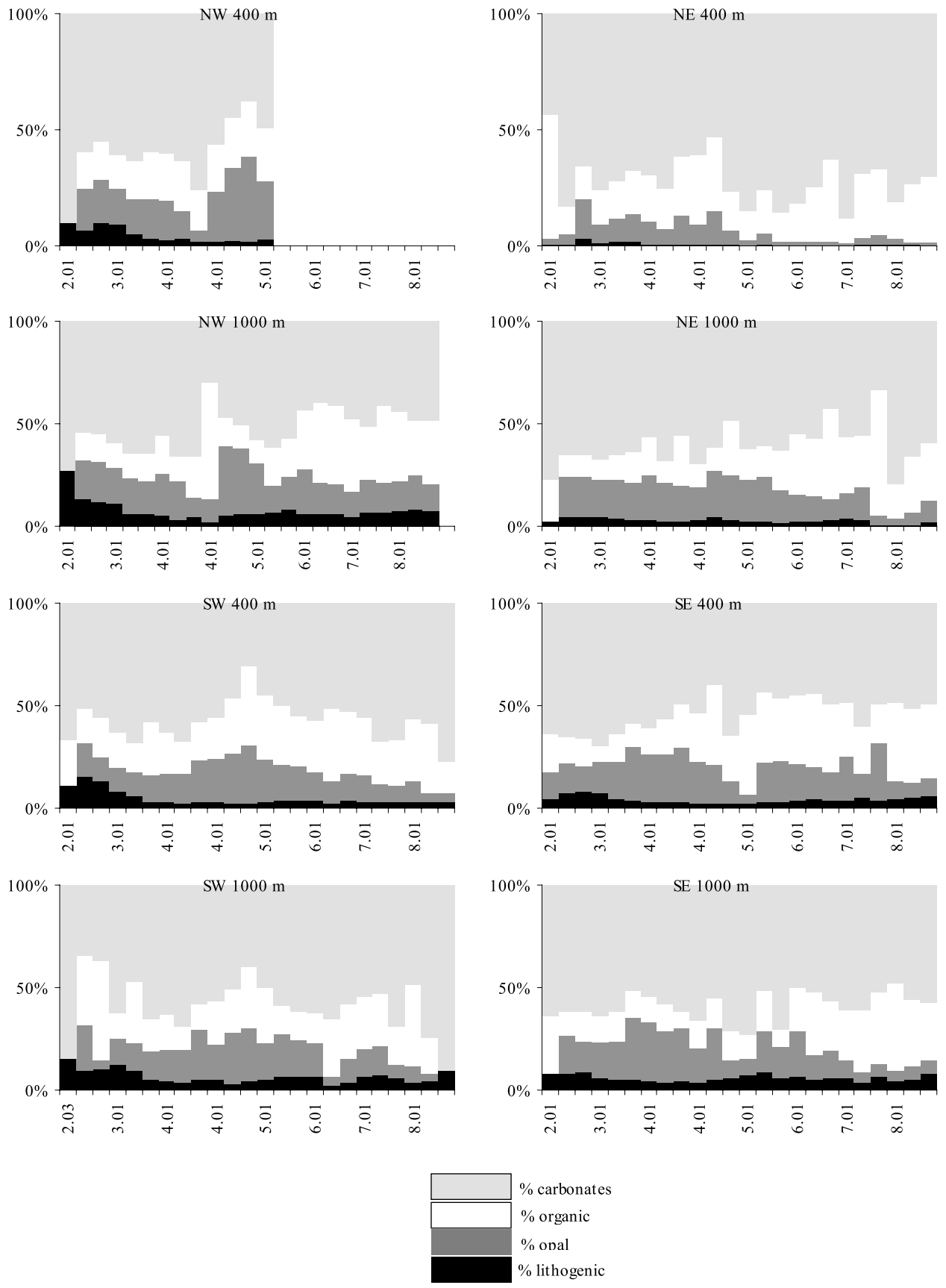

Figure 5. Spatial and temporal variability of the composition of the exported material (each fraction as a percentage of the total (100\%) material collected; $y$ axis). 

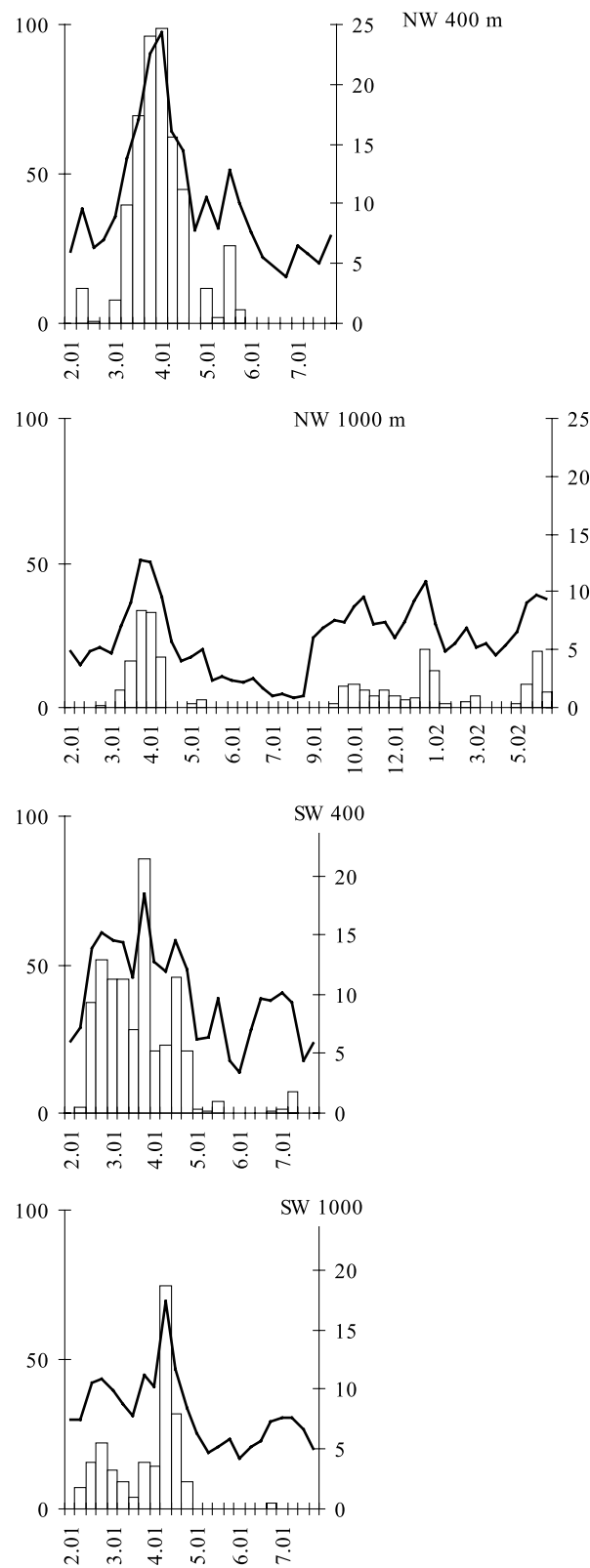
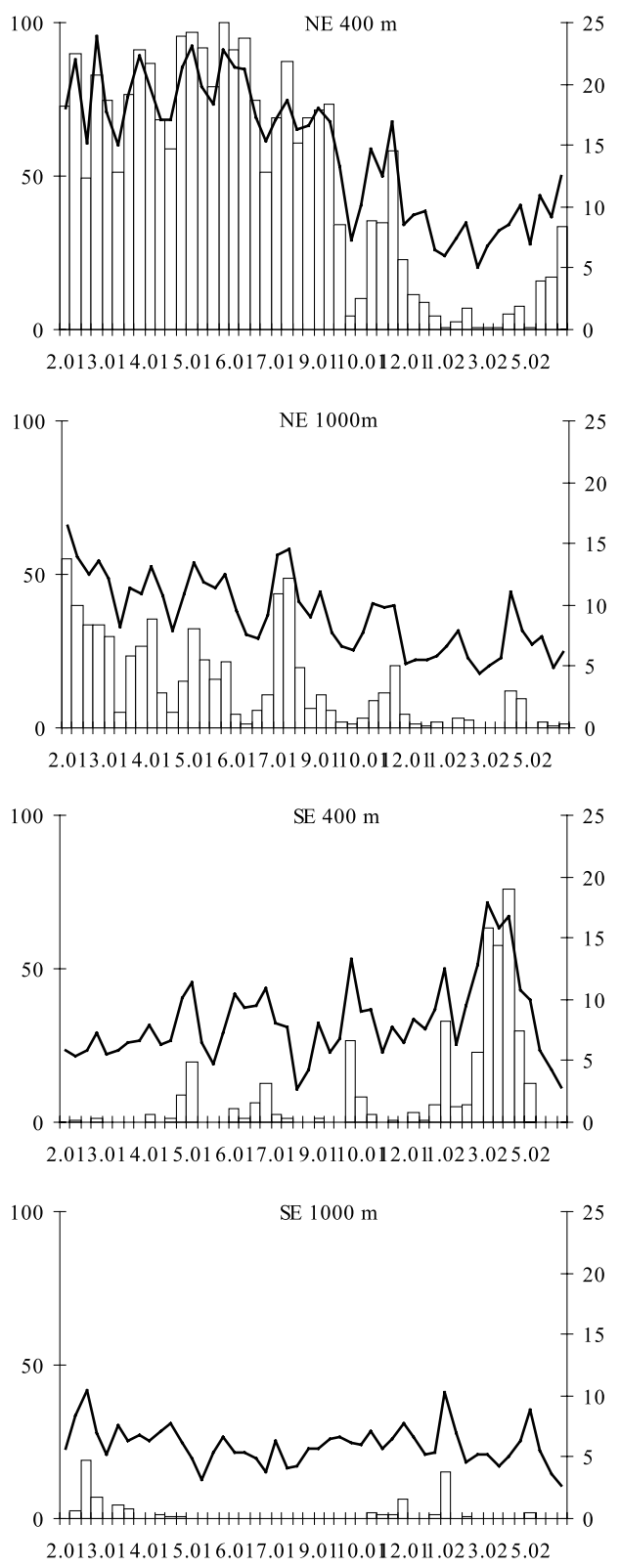

Figure 6. Current speed from February 2001 to June 2002: percentage speed $>15 \mathrm{~cm} \mathrm{~s}^{-1}$; white bars (left scale, maximum $=100 \%$ ). Speed $\left(\mathrm{cm} \mathrm{s}^{-1}\right)$ averaged over the collection period of each cup: bold line (right scale). (No available data for the second deployment of the northwest site at $400 \mathrm{~m}$ due to a water leak into the current meter.)

inclinations of $\sim 2^{\circ}-3^{\circ}$ and depth variations of $\sim 50 \mathrm{~m}$ at $400 \mathrm{~m}$ depth, which compares well with observed values. The $1000 \mathrm{~m}$ depth sediment traps were not fitted with inclinometers. Computations show that maximum angles at that level are of order $\sim 5^{\circ}-6^{\circ}$, slightly over twice the value at $400 \mathrm{~m}$. Depth variation are in the same range.

\section{Discussion}

\subsection{Sediment Trap Efficiency and Particulate Flux Estimation}

[29] It is well established that sediment trap collection efficiency can be reduced by hydrodynamic effects leading to biased estimates of the particulate fluxes [Baker et al.,
1988; Buesseler, 1991; Gardner, 1980]. Thorium-230 is widely used to estimate sediment trap efficiency [Bacon et al., 1985; Scholten et al., 2001; Yu et al., 2001]. This radioactive isotope (half-life $=75,690$ years) is produced uniformly in the ocean by radioactive decay of ${ }^{234} \mathrm{U}$ and it is rapidly scavenged on settling particles and removed from the water column [Bacon and Anderson, 1982]. The trapping efficiency is obtained by comparing the ${ }^{230} \mathrm{Th}_{e x}$ flux collected by the trap with the ${ }^{230} \mathrm{Th}$ production in the overlying water column. The ${ }^{230} \mathrm{Th}$ particulate flux collected by the sediment trap varies strongly seasonally, so that at a given time it is not necessarily equal to the in situ production [Bacon et al., 1985; Scholten et al., 2001]. Considering that the interannual variability of the flux should be much smaller than the 


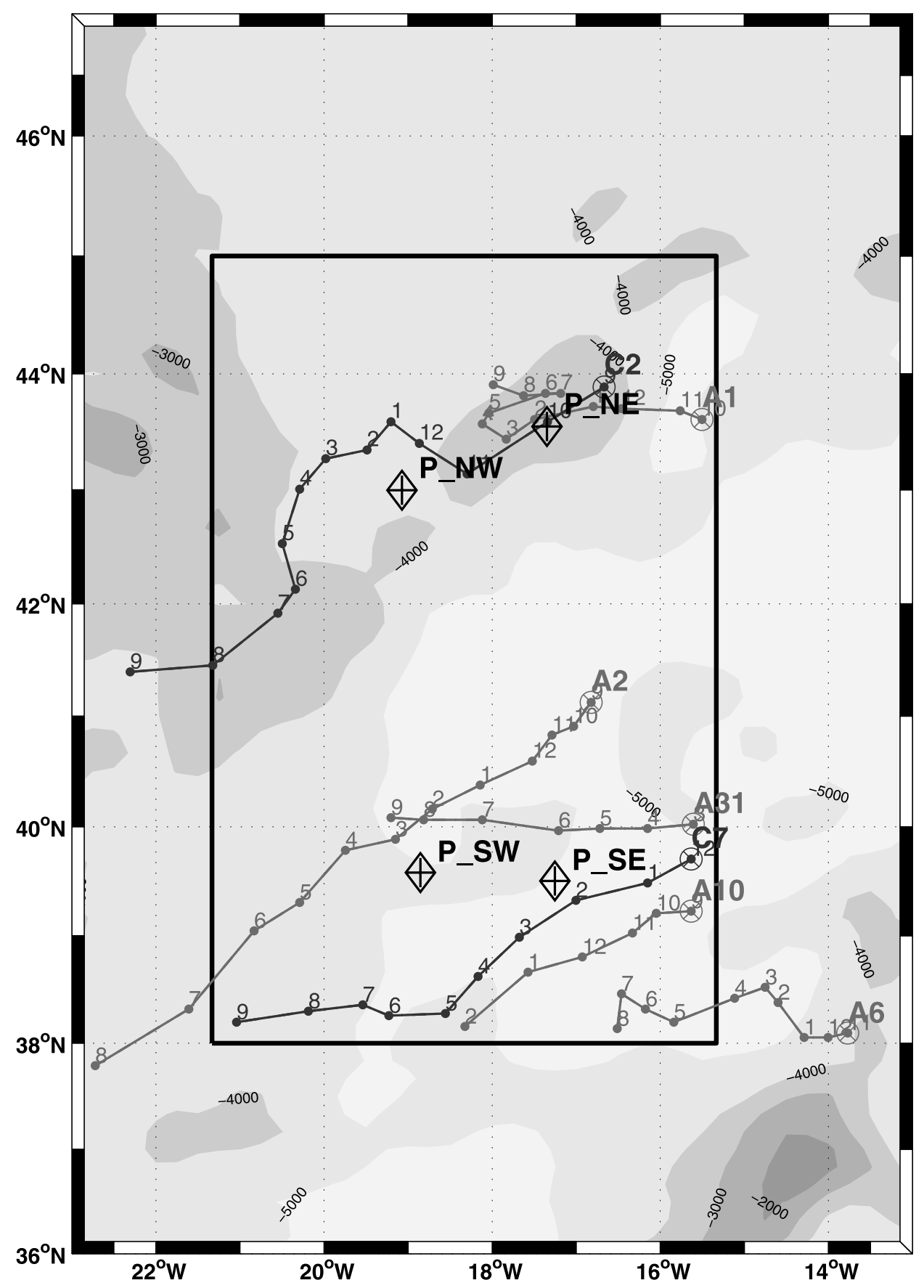

Figure 7. Map of selected eddy displacements in the POMME area in the vicinity of the trap moorings from September 2000 to September 2001. The tracks connect the monthly averaged positions of the center of each labeled eddy (month indicated by the numbers; cross and name of the eddy are located at the beginning of its track). Trap moorings are indicated by crossed diamonds. See Le Cann et al. [2005] for details.

seasonal variability, the trapped flux averaged over year $(F)$ is compared to the yearly in situ production of the water column overlying the trap $(P)$. The efficiency $E$ is given by

$$
E=F / P \text {. }
$$

[30] We estimate the trapping efficiency of each trap by determining the ${ }^{230} \mathrm{Th}_{e x}$ flux over the first year of collection.
For the NE400, NE1000, SE1000 and NW1000 a full year was analyzed so that a direct comparison of the ${ }^{230} \mathrm{Th}_{e x}$ flux with the annual production is possible. The collected ${ }^{230} \mathrm{Th}_{\text {ex }}$ flux represents a variable fraction of the annual in situ production: $18.5 \%$ for NE400, 32\% for NE1000, 33\% for NW1000 and 34\% for SE1000. The SW traps did not collect for a full year but only from late winter to summer 2001. The trapping efficiencies can be bracketed with two 
extreme hypotheses. If during the unsampled period (from late summer to early winter) the average ${ }^{230} \mathrm{Th}$ fluxes were the same as during the sampling period, the trapping efficiencies are $37 \%$ for SW 1000 and $58 \%$ for SW400. They are upper limits because ${ }^{230} \mathrm{Th}$ particulate fluxes are expected to be lower from summer to winter than during the bloom period [Bacon et al., 1985; Scholten et al., 2001]. On the other hand, if the ${ }^{230} \mathrm{Th}$ particulate flux was equal to zero during the unsampled period, the trapping efficiency are $18 \%$ for SW 1000 and $29 \%$ for SW400. They are lower limits because, there is always a ${ }^{230} \mathrm{Th}$ particulate flux from summer to winter. Finally, we average these extreme values to obtain ranges of $43.5 \pm 14.5 \%$ for SW400 and $27.5 \pm$ 9.5\% SW1000. For NW400, no samples were collected from June to early September, at the transition between the productive period and the low-flux period. Therefore we assume conservatively that for the missing samples the ${ }^{230} \mathrm{Th}_{x s}$ flux was bracketed by the ${ }^{230} \mathrm{Th}_{x s}$ fluxes averaged over the beginning of the year $\left(398 \mathrm{fg} \mathrm{m}^{-2} \mathrm{~d}^{-1}\right.$ ) and the end of the year $\left(38 \mathrm{fg} \mathrm{m}^{-2} \mathrm{~d}^{-1}\right)$. This yields an efficiency of $28.5 \pm 6.5 \%$. For SW 400, samples were collected all over the year but the ${ }^{230} \mathrm{Th}_{x s}$ concentrations were not measured for the sample collected between September to December 2001. Noting that there is a gross correlation between the mass flux and the ${ }^{230} \mathrm{Th}_{x s}$ flux, we estimate upper (lower) bound of the ${ }^{230} \mathrm{Th}_{x s}$ flux range by multiplying the mass flux by the highest (the lowest) ${ }^{230}{ }^{2} h_{x s}$ concentration measured at NW400. This yields an average efficiency of $55 \pm 4 \%$. The results obtained for the POMME traps are consistent with those published for the Eastern North Atlantic at similar depths [Scholten et al., 2001; Yu et al., 2001]. These estimates correspond roughly to a mean efficiency, whereas the real efficiency probably varies with time due to changes of current speed and particle dynamics. In the framework of POMME, attempts are made to constrain the trapping efficiency on a seasonal basis [RoyBarman et al., 2003].

[31] Equation (1) assumes that ${ }^{230} \mathrm{Th}_{e x}$ is carried only by settling particles whereas the horizontal transport by currents toward continental margins may not be negligible [Bacon et al., 1985]. In section 4.3, it will be argued that particles originating from the European margin may be transported to the POMME area. The question of the exchange between the open ocean and the ocean margin can be addressed by measuring both ${ }^{230} \mathrm{Th}$ and ${ }^{231} \mathrm{~Pa}$ in the traps. In the present study, ${ }^{231} \mathrm{~Pa}$ was not measured. However several ${ }^{230} \mathrm{Th}$ and ${ }^{231} \mathrm{~Pa}$ studies have shown that boundary scavenging has a reduced influence on the ${ }^{230} \mathrm{Th}$ and ${ }^{231} \mathrm{~Pa}$ in the eastern North Atlantic and that it should not strongly affect our results [Scholten et al., 2001; Yu et al., 2001]. In the POMME area, the subduction of mode water potentially brings ${ }^{230} \mathrm{Th}_{e x}$ poor water at depth that it could affect the ${ }^{230} \mathrm{Th}$ balance. However, the linear profiles of dissolved + particulate ${ }^{230} \mathrm{Th}$ observed in the water column below the mixed layer indicate that ventilation by ${ }^{230} \mathrm{Th}-$ poor water is not significant [Roy-Barman et al., 2003].

[32] From the above discussion, it is clear that the ${ }^{230} \mathrm{Th}_{e x}$ flux intercepted by the traps are well below the production rate in the overlying water column and that it must be due to the poor collection efficiency of the particles carrying ${ }^{230} \mathrm{Th}_{e x}$ by the traps. Thus the ${ }^{230} \mathrm{Th}_{e x}$ budget potentially allows to correct these trapping efficiency problems. How-

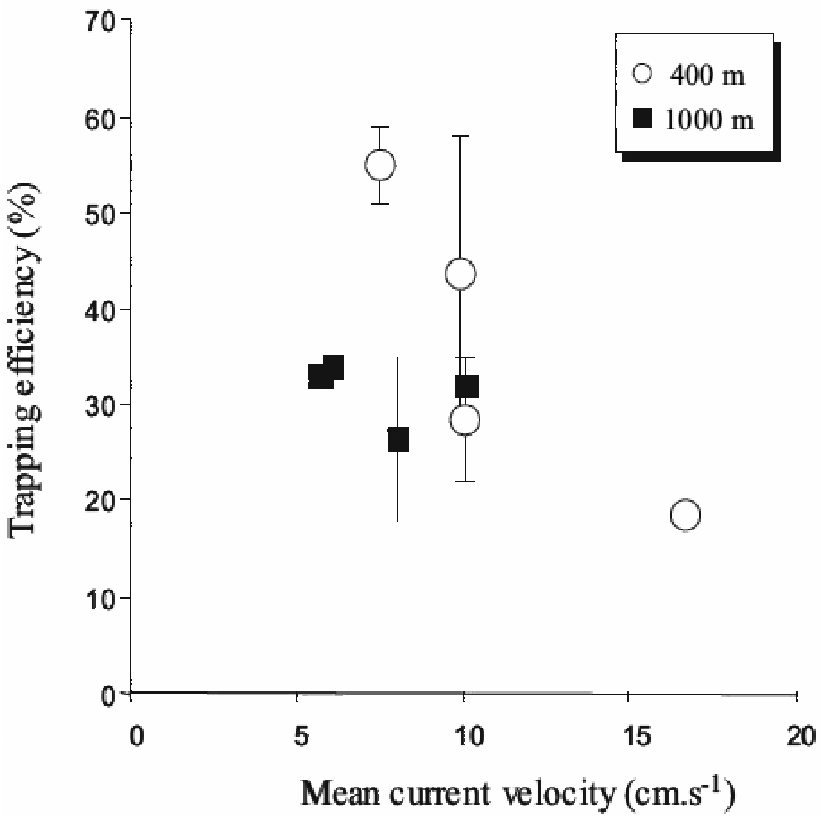

Figure 8. Trapping efficiency versus current speed. The data represent the trapping efficiency calculated from ${ }^{230} \mathrm{Th}_{e x}$ flux intercepted by the traps between February 2001 and February 2002; the current speed, measured continuously at $400 \mathrm{~m}$ and $1000 \mathrm{~m}$, were averaged for the same period.

ever, this correction is relevant only if the particles carrying ${ }^{230} \mathrm{Th}_{e x}$ are not lost preferentially compared to the bulk particulate flux. There is an ongoing debate concerning the type of particles carrying ${ }^{230} \mathrm{Th}_{e x}$ [Chase and Anderson, 2004; Luo and Ku, 2004; Geibert and Usbeck, 2004]. So, the question of whether or not the ${ }^{230} \mathrm{Th}_{e x}$ correction factors must be applied to all chemical elements in the trapped material and in particular to POC remains open. The good agreement between efficiency corrected particle flux collected in the mesopelagic zone and modeled particle flux is in favor of taking into account the efficiency of the traps [Usbeck et al., 2003]. In the following discussion, all the POMME fluxes that we will consider will be corrected for trapping efficiency. We will also compare the POMME fluxes corrected for trapping efficiency with fluxes from other studies for which these corrections are also available.

[33] There is not a consistent relationship between the trapping efficiency and the average current speed around the traps (Figure 8). However, when taken separately, the $400 \mathrm{~m}$ and the $1000 \mathrm{~m}$ traps show two different trends. At $400 \mathrm{~m}$, the trapping efficiency decreases when the mean current speed increases. While this trend might be fortuitous, it corresponds to the relation expected from hydrodynamic considerations. By contrast, at $1000 \mathrm{~m}$, the trapping efficiency is constant and independent of the current speed. The causes of these contrasted behaviors are not clear. It might be due to the evolution of the sinking particles between 400 and $1000 \mathrm{~m}$ (desegregation of large aggregates, repackaging of the particles by grazing). It might as well reflect the fact that for sediment traps moored on the same line, the trap at $1000 \mathrm{~m}$ is much more tilted by the current (and therefore less efficient) than the trap at $400 \mathrm{~m}$ (see section 3.5). Such 

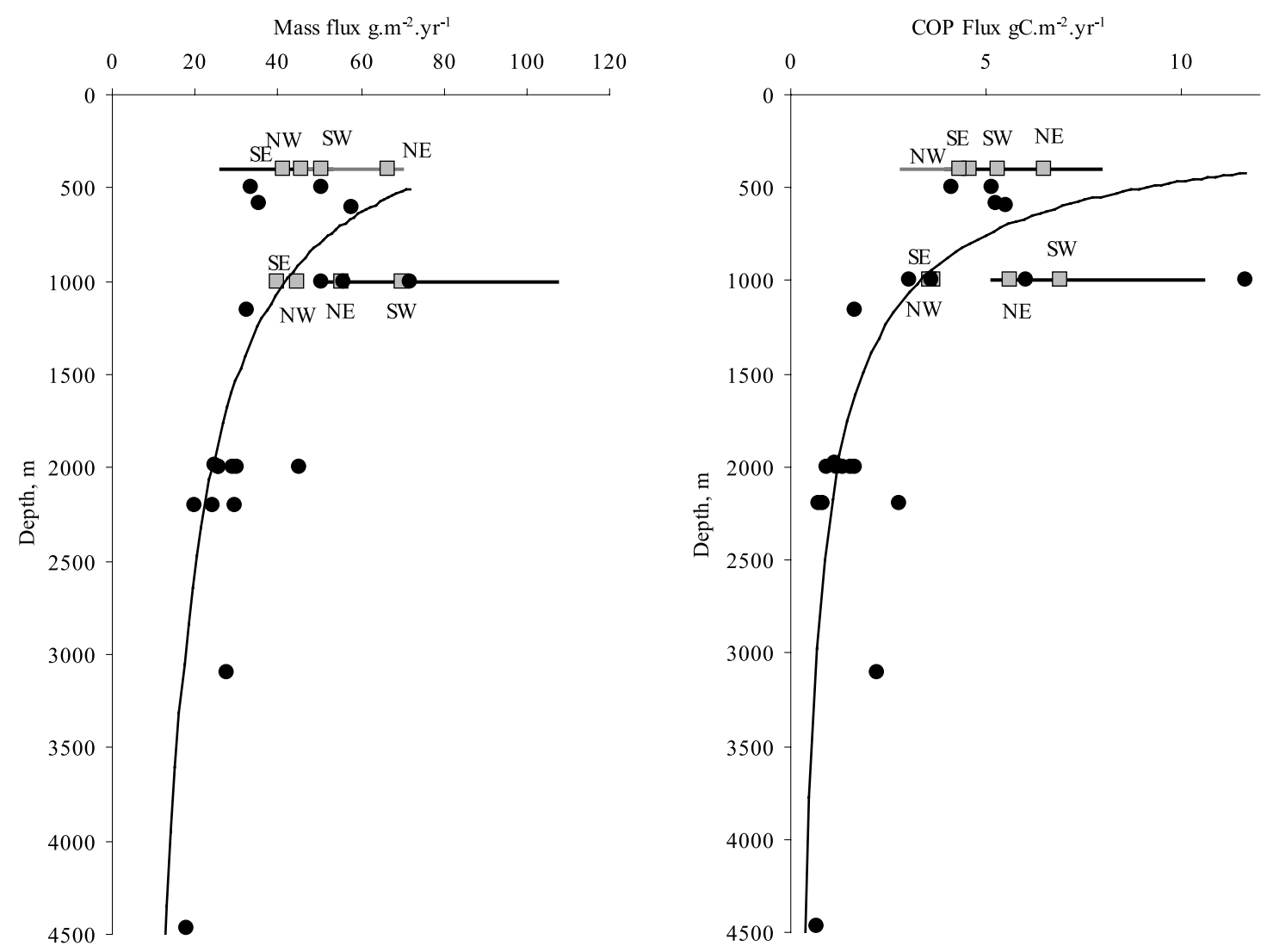

Figure 9. Mass and POC flux: comparable data in the vicinity of the POMME area. Data for the four moorings in the POMME quadrangle along with data taken from Table 3 when ${ }^{230}$ Th correction was available. All data corrected from ${ }^{230} \mathrm{Th}$.

relationships have not been found in other studies, but this might just be because they covered large ranges of sediment trap and sinking particle types leading to very different hydrodynamic bias [Scholten et al., 2001; Yu et al., 2001].

\subsection{Downward Fluxes Over the POMME Area and POC Export: Comparison With Primary Productivity}

[34] Downward fluxes at 400 and $1000 \mathrm{~m}$ for the POMME area along with the data available from the literature for studies in adjacent areas are reported in Figure 9 (left) and Table 3. In previous studies, the average for mass fluxes measured at or above $1000 \mathrm{~m}$ is $\sim 51 \mathrm{~g} \mathrm{~m}^{-2}$ $\mathrm{yr}^{-1}$. They tend to be higher above $1000 \mathrm{~m}$, the highest fluxes being of the order of $70 \mathrm{~g} \mathrm{~m}^{-2} \mathrm{yr}^{-1}$. The data for the POMME moorings at $400 \mathrm{~m}$ and $1000 \mathrm{~m}$ are in the same range as the literature data. Taking into account the uncertainty of the ${ }^{230} \mathrm{Th}$ correction, they fit with those previously established.

[35] For the evolution of the POC fluxes as a function of depth, the POMME data compare very well with the published data in the vicinity of the POMME area (Figure 9 (right) and Table 3). If station L3 (to the north of the region considered), is not taken into account, there is less than one order of magnitude between all the POC fluxes. At the SW site, the uncertainty on the trapping efficiency is high, so it is difficult to provide any quantitative comparison between flux at 400 and $1000 \mathrm{~m}$. Except for the SW site, our data indicate that the POC flux decreases with depth. This decrease is consistent with the POC mineralization during its settling through the water column. As already noted by Antia et al. [2001a, 2001b], this decrease is not visible when data are not corrected for trapping efficiency (Figure 10).

[36] Finally, although the POMME quadrangle experienced a relatively high mesoscale activity [Le Cann et al., 2005], POC export is rather homogeneous at $1000 \mathrm{~m}$ over the POMME area: we estimate that $4.9 \pm 1.6 \mathrm{gC} \mathrm{m}^{-2} \mathrm{yr}^{-1}$ were exported to deep waters between February 2001 and February 2002 (Table 3).

[37] Still there seems to be a higher export at $400 \mathrm{~m}$ in the northern part of the POMME zone compared to the southern part. This could be both due to the effect of mesoscale activity (see below) or it could be also related to the productivity gradient between the subtropical and the subpolar North Atlantic.

[38] The exported organic carbon collected at 400 and $1000 \mathrm{~m}$ was compared with the amount of carbon produced in the surface layer. The available data of average surface values for carbon uptake rates measured during the first legs of the POMME 2 (16 April to 7 May) and POMME 3 (18 September to 10 October) cruises in 2001 [Fernández et al., 2005b], are compared with the average POC fluxes measured at the four moorings during the same period (Table 5).

[39] It appears that export efficiency was higher during spring (maximum export of 5\% of the PP and on average $3.2 \%$ at $400 \mathrm{~m}$ and maximum export of $2.8 \%$ and on 


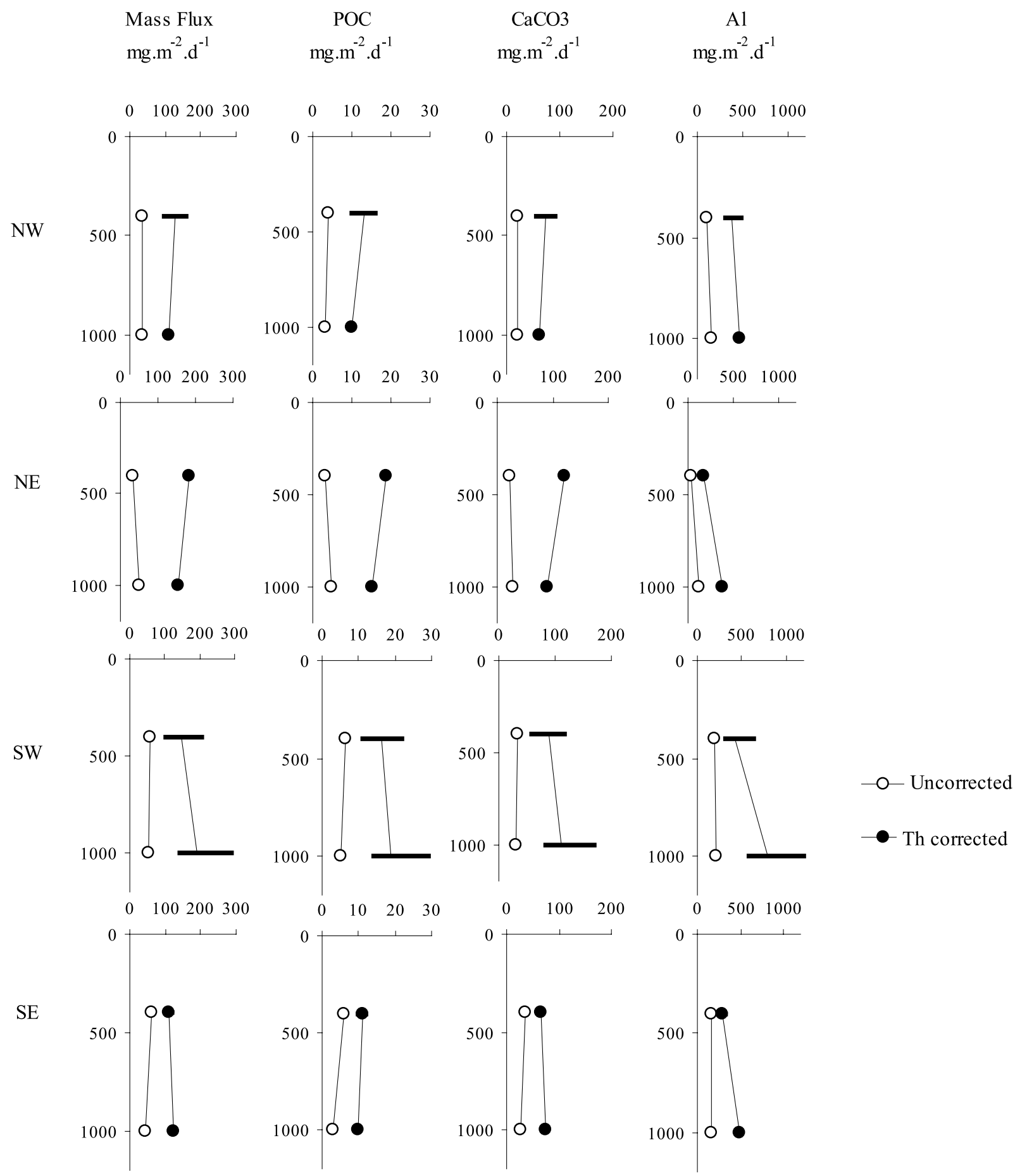

Figure 10. Comparison of the average fluxes for the period February 2001 to February 2002 without and with correction from ${ }^{230} \mathrm{Th}$.

average $2.2 \%$ at $1000 \mathrm{~m}$ during POMME 1 ; maximum export of $3.1 \%$ and on average $2.1 \%$ at $400 \mathrm{~m}$ and maximum export of $2 \%$ and on average 1.0 at $1000 \mathrm{~m}$ during POMME 3). Export efficiency was lower during the low-production season due to the intense regenerated production that occurs under such trophic regimes. At all sites, the exported fraction was lower at $1000 \mathrm{~m}$ than at $400 \mathrm{~m}$ reflecting remineralization process. Decoupling between the primary and the export productions has already been ob- served [Buesseler, 1998]. While it is accepted that the phytoplankton taxonomy is important for the preservation of the export production, the role of each family is still debated. Blooms of large diatoms produce rapidly sinking aggregates that rapidly carry POC to depth [Boyd and Newton, 1995; Loecht et al., 1993]. During the spring bloom, diatoms (pseudo nitzchia spp.) provided a noticeable fraction of the primary production [Leblanc et al., 2005]. However, opal represents only a minor fraction of the total 
Table 5. Comparison of the Primary Production From Measurements Performed During Leg 1 of the Two Cruises (POMME 2 and POMME 3), Along With the POC Export Calculated From Traps for the Same Period ${ }^{\mathrm{a}}$

\begin{tabular}{lcc}
\hline & POMME 2 & POMME \\
\hline \multicolumn{1}{c}{ Average Surface Values for Carbon Uptake Rates $\left(m g \mathrm{~m} \mathrm{~m}^{-2}\right.$} & $\left.d^{-1}\right)^{\mathrm{b}}$ \\
North zone & 1060 & 459 \\
South zone & 1607 & 379 \\
& & \\
& POC Fluxes From Traps $\left(\mathrm{mgC}^{-2} \mathrm{~d}^{-1}\right)$ & 7.6 \\
NW $400 \mathrm{~m}$ & 37.9 & 8.8 \\
NW $1000 \mathrm{~m}$ & 22.4 & 14.1 \\
NE $400 \mathrm{~m}$ & 52.5 & 9.0 \\
NE $1000 \mathrm{~m}$ & 29.4 & no data \\
SW $400 \mathrm{~m}$ & 46.2 & no data \\
SW $1000 \mathrm{~m}$ & 43.3 & 5.5 \\
SE $400 \mathrm{~m}$ & 25.5 & 7.1 \\
SE $1000 \mathrm{~m}$ & 20.2 & \\
& & \\
Average Percentage of the Primary Production Exported at Depth as \\
& Particles (\%) & 3.1 \\
NE $400 \mathrm{~m}$ & 5.0 & 2.0 \\
NE $1000 \mathrm{~m}$ & 2.8 & 1.7 \\
NW $400 \mathrm{~m}$ & 3.6 & 1.9 \\
NW $1000 \mathrm{~m}$ & 2.1 & 1.4 \\
SE $400 \mathrm{~m}$ & 1.6 & 1.9 \\
SE $1000 \mathrm{~m}$ & 1.3 & \\
SW $400 \mathrm{~m}$ & 2.9 & \\
SW $1000 \mathrm{~m}$ & 2.7 &
\end{tabular}

${ }^{\text {a}}$ Primary production measurement values are from Fernández et al. [2005b] and Fernández [2003]. Data for POMME 1 are not discussed because of the lack of trap data for this period. Data are corrected from ${ }^{230}$ Th calibration.

${ }^{\mathrm{b}}$ Measured during the first legs of the POMME cruises (2001).

trapped particulate matter. On the other hand, calcifying cells are thought to allow a better preservation of POC than diatoms through an efficient ballasting [Francois et al., 2002]. This hypothesis is consistent with the fact that high fluxes correspond to high $\mathrm{CaCO}_{3}$ fraction in the traps (Figure 5). These two processes are all the more important because the POMME area is not directly under the influence of the Saharan dust plume that provides an important lithogenic ballasting [Bory et al., 2001]. Finally, the efficiency of organic matter mineralization is generally high in summer because a large fraction of the autotrophic producers are small, individual, testless cells that sink very slowly and can be efficiently regenerated by bacteria. It has been showed recently by Lutz et al. [2002] that only $0.1-$ $8.8 \%$ (average $1.1 \%$ ) of primary production enters the deep ocean $(<1.5 \mathrm{~km})$. Our estimated rate of the order of $2 \%$ at $1000 \mathrm{~m}$ is within this range. In the POMME area the $f$ ratio (new production/primary production) is of the order of $30 \%$ [Fernández et al., 2005b] so that the POC export represents only $4-15 \%$ of the new production. This implies that in the POMME area, most of the organic carbon export is not done by particle settling but rather by DOC transport through winter convection and mode water circulation.

[40] This is in agreement with modeling results of the POMME area [Lévy et al., 2005a]. It must be also noted that the increase of DOC observed between $300 \mathrm{~m}$ and $1000 \mathrm{~m}$ from winter to summer $\left(\approx 25 \mathrm{gC} \mathrm{m}^{-2}\right.$ (R. Fukuda-Sohrin and R. Sempéré, Seasonal distribution in total organic carbon in the northeast Atlantic in 2000-2001, submitted to Journal of Geophysical Research, 2004)) cannot be solely due to the dissolution of the particulate flux collected by the traps $\left(\approx 5 \mathrm{gC} \mathrm{m}^{-2} \mathrm{yr}^{-1}\right)$ and suggests also advective processes.

[41] It was recently suggested that in shallow sediment traps, a large fraction of the POC collected by the trap could be lost as DOC [Kähler and Bauerfeind, 2001]. While we cannot exclude that the POMME samples have experienced some POC loss, we think that it should not significantly alter our previous conclusion. First, we note that Kähler and Bauerfeind [2001] consider that at $1000 \mathrm{~m}$, the most labile POC has been dissolved so that the POC content of the trapped material should not change significantly in the trap. Second, should the POC dissolution described by Kähler and Bauerfeind [2001] occur in the POMME traps, the POC fluxes would be underestimated by a factor 2.7 , but even if we increase the POC flux by $170 \%$, the exported production represents only $10-40 \%$ of the new production.

\subsubsection{Barium Contribution}

[42] At $400 \mathrm{~m}, \mathrm{Ba}_{x s}$ values are comparable between the four sampling sites when averaged over the whole period, although the time series display a large scatter (NE: $520 \pm$ 414; NW: $551 \pm 559$; SE: $531 \pm 363$; SW: $529 \pm 167$, all expressed in $10^{-6} \mathrm{~g} \mathrm{~g}^{-1}$ ). At $1000 \mathrm{~m}$, average $\mathrm{Ba}_{x s}$ values are larger than at $400 \mathrm{~m}$ for both northern sites (NE: $863 \pm$ 452 and NW: $850 \pm 365 \times 10^{-6} \mathrm{~g} \mathrm{~g}^{-1}$ ) whereas values do not increase so markedly with depth at the southern sites (SE: $698 \pm 376$ and SW $669 \pm 277 \times 10^{-6} \mathrm{~g} \mathrm{~g}^{-1}$ ). These values are two to three times larger than those observed during OMEX I and II [Dehairs et al., 2000; Fagel et al., 2004] in traps moored along the European margin.

[43] Fractions of biogenic $\mathrm{Ba}\left(\mathrm{Ba}_{x s}\right)$ in the bulk samples range from $80 \%$ to more than $98 \%$ of total $\mathrm{Ba}$, most of the samples showing values larger than $96 \%$. These high values indicate that $\mathrm{Ba}$ is mainly of biological origin and that the inputs of lithogenic $\mathrm{Ba}$ are low in the POMME area. The increase of $\mathrm{Ba}$ content with depth is consistent with the observation that barite is formed in the upper layers of the water column by precipitation in decaying organic matter [Turekian and Tausch, 1964; Bishop, 1988]. An ubiquitous suspended barite crystal maximum occurs at many locations in the mesopelagic layers (250-600 m [Cardinal et al., 2001, and references therein]). The uptake of ${ }^{228} \mathrm{Ra} /{ }^{226} \mathrm{Ra}$ by barite was used to demonstrate that barite was formed in the upper $400 \mathrm{~m}$ of the tropical NE Atlantic Ocean [Legeleux and Reyss, 1996] and down to $1000 \mathrm{~m}$ in the Bermuda water column [van Beek et al., 2004]. As the full development of barite crystals is expected to happen deeper than $400 \mathrm{~m}$, we only used the $1000 \mathrm{~m}$ data to establish the possible link between average $\mathrm{Ba}_{x s}$ fluxes and surface productivity. Average corrected $\mathrm{Ba}_{x s}$ flux values were of $4.7 \pm 3.8(\mathrm{NE}), 3.6 \pm 3.3(\mathrm{NW})$, $2.8 \pm 2.1(\mathrm{SE})$ and $4.5 \pm 4.1(\mathrm{SW}) \mathrm{mg} \mathrm{cm}^{-2} \mathrm{yr}^{-1}$.

[44] Since the POMME area is located in the middle of the northeast Atlantic basin, these data can be compared to values obtained in traps moored (1) in neighboring areas and/or (2) corrected for the collection bias. Although the uncertainties affecting the POMME average $\mathrm{Ba}_{x s}$ fluxes are large, our data show $\mathrm{Ba}_{x s}$ annual fluxes slightly higher or similar to those observed during the NABE experiment $(2.5$ and $2.7 \mathrm{mg} \mathrm{cm}^{-2} \mathrm{yr}^{-1}$ at $34^{\circ} \mathrm{N}$ and $48^{\circ} \mathrm{N}$ respectively). They are also comparable to the EUMELI mesotrophic site 


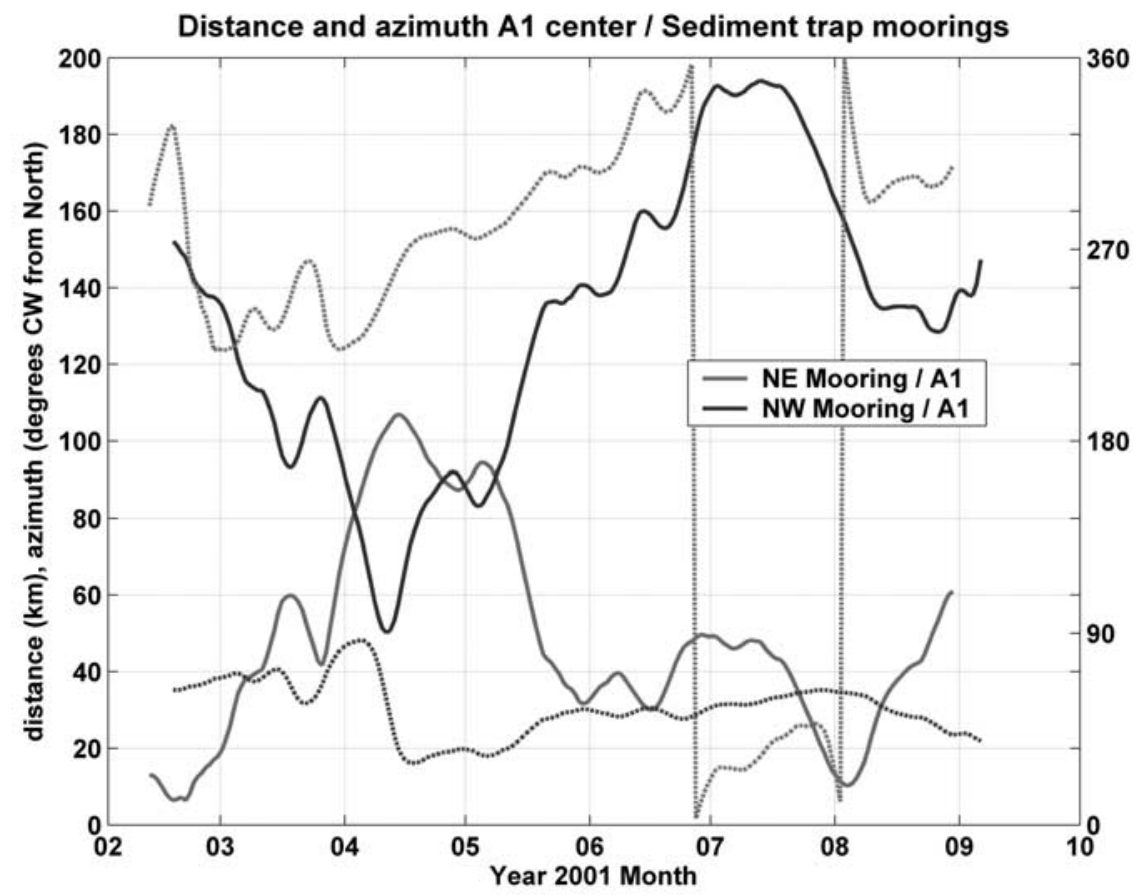

Figure 11. Distances $(\mathrm{km})$ (solid lines) and azimuths (degrees from north) (dashed lines) of the center of eddy A1 from the northwest and northeast trap moorings.

(3.6 $\mathrm{mg} \mathrm{cm} \mathrm{cm}^{-2} \mathrm{yr}^{-1}$ ), although these last values were not corrected for trapping efficiency [Jeandel et al., 2000].

[45] The average $\mathrm{POC} / \mathrm{Ba}_{x s}$ ratios $(\mathrm{w} / \mathrm{w})$ are of 117.7 at the NE site, 140.6 at the NW site and 103.1 at the SE site. These values are significantly higher than the range predicted by the relationship between both parameters proposed by Francois et al. [1995] for the global ocean, ranging from 60 to 80 at $1000 \mathrm{~m}$. However, a closer look to these authors' data reveals that they observe $\mathrm{POC} / \mathrm{Ba}_{x s}$ ratio similar to ours in the western Atlantic (Hatteras, Nares, Demerara abyssal plains and Sargasso Sea), whereas ratios observed during NABE in the eastern Atlantic are comparable to the global one. Although the sampling locations are far from any margin, the high $\mathrm{POC} / \mathrm{Ba}_{x s}$ ratios observed during POMME could be due to the advection of refractory carbon, as is the case at margins [Dehairs et al., 2000; Fagel et al., 2004]. Indeed, lateral inputs are suggested by the increase of Al fluxes with depth (see below). They could also reflect the good preservation of the organic carbon during the vertical settling of the particles, enhanced by the high fraction of carbonates found in all the traps (around $60 \%$ ). This would be consistent with the hypothesis of Francois et al. [2002] underlined above: the more the surface productivity was dominated by calcium carbonate skeleton species, the more the organic carbon was efficiently preserved compared to other situations (opal or lithogenic ballasts). Note that the relatively low $\mathrm{POC} / \mathrm{Ba}_{x s}$ ratios observed at NABE, area characterized by coccoliths' blooms, argue against this hypothesis. If the $\mathrm{POC} / \mathrm{Ba}_{x S}$ ratio is significantly governed by biological parameters, the relationship between $\mathrm{Ba}_{x s}$ and export production proposed by Francois et al. [1995] has to be considered cautiously. In addition, the
Francois et al. [1995] relationship was established using uncorrected $\mathrm{Ba}_{x s}$ fluxes. Nevertheless, based on the average $\mathrm{Ba}_{x s}$ fluxes collected at $1000 \mathrm{~m}$ and given the above empirical relationship we estimate export productions at the NE, NW, SE and SW sites of about 17.3, 11.9, 8.3 and $16.3 \mathrm{gC} \mathrm{m}^{-2} \mathrm{yr}^{-1}$ respectively. These values are significantly lower than the new production of $58 \mathrm{gC} \mathrm{m}^{-2} \mathrm{yr}^{-1}$ averaged over the POMME area [Fernández et al., 2005b] but 2-3 times larger than the average POC fluxes measured at $400 \mathrm{~m}$ at each sites (Table 3). This discrepancy is not surprising considering (1) the fact that POC remineralization might have occurred between the exit from the mixed layer and the traps' depth and (2) the uncertainties affecting Francois et al.'s [1995] relationships.

\subsubsection{Influence of the Mesoscale Circulation}

[46] Among the 4 fixed moorings deployed during the POMME experiment, one was particularly exposed to mesoscale activity and thus offers the opportunity to study the influence of such structure on the carbon export. According to Le Cann et al. [2005], a persistent anticyclonic eddy named A1 was in the vicinity of the NE mooring during the whole first deployment with a maximum distance between the center of the eddy to the position of the mooring of $100 \mathrm{~km}$. The center of the eddy was in very close vicinity of the mooring at the beginning of the experiment (in February) and at the beginning of August (Figure 11). As previously discussed, this site had the highest current speed recorded among the all sites, in particular at $400 \mathrm{~m}$ depth. The weak correlation between the distance (eddy center, NE site) and the speeds recorded at NE, between 20 and $60 \mathrm{~km}$ and the slow decrease of current speed at radiuses from $60 \mathrm{~km}$ to $100 \mathrm{~km}$ 
was discussed above. As a result, the current speeds were constantly high during the whole period.

[47] The NE site has two peculiarities compared to the other sites: (1) the composition of the sinking material is different and (2) a strong $\mathrm{C}$ export occurred during summer. Indeed, the NE site presents a particularly low proportion of lithogenic material among the collected particles (less than $1 \%$ at $400 \mathrm{~m}$ ). In addition, opal represents a very small fraction of the material collected at $400 \mathrm{~m}$ (despite the strong diatom production, but this might be due to a fast dissolution of Bsi); furthermore, this site has the higher proportion of calcium carbonate. POC export during summer was shown to be higher than during the spring bloom event in particular at NE $1000(+162 \%)$; comparable high summer export was also observed for the NW 1000 site (152\% of the export during the bloom) and SW 400 (143\%) and export at SE 1000 site was equivalent during the spring and the summer period (Table 4). The POC flux reveals a much stronger POC export at NE 400 than at the other sites. This strong export at the NE site can be related in part to the deep winter mixed layer found to the North of the POMME zone that fuels the surface water with nutrients which are consumed during the spring bloom. However there is also a clear role for the mesoscale activity: the A1 anticyclonic eddy is associated with a deepening of the permanent thermocline but also with a shoaling of the seasonal thermocline and of the associated nutracline. This process produces a significant recharge of the photic zone with nitrate during the summer [Fernández et al., 2005a]. This high nitrate level induces a large amount of new production compared to the rest of the zone and allows for a strong summer POC export, in particular at NE $1000 \mathrm{~m}$. Rather than a decoupling between export at 400 and $1000 \mathrm{~m}$, the fact that POC export was higher at $1000 \mathrm{~m}$ may be due to funnel effect that allowed the trap at $1000 \mathrm{~m}$ to be longer under the influence of A1.

[48] Similarly in the southwest of the POMME area, the core of the A2 anticyclonic eddy (see track on Figure 7) has a high nitrate level due to an uplift of the nitrate isolines. During early spring, it is associated with a high primary production rate and the highest new production measured during the POMME study [Fernández et al., 2005a]. Carbon export at the SW site was among the highest recorded during spring 2001 (Table 5); at this time, the center of the A2 eddy was within $\approx 50 \mathrm{~km}$ of the SW trap (Figure 11).

[49] To understand when and how long the trap have been under the dynamical influence of the eddies, it is important to note that the material in the traps is not produced strictly in a vertical column above the trap [Waniek et al., 2000]. It may originate from everywhere within a large "statistical funnel" due to the transport of the particle by horizontal currents. The horizontal eddy diffusion coefficient $(K)$ is on the order of $10^{3} \mathrm{~m}^{2} \mathrm{~s}^{-1}$ in the POMME area [Reverdin et al., 2005]. The average horizontal distance $(d)$ traveled by the particle by eddy transport is $\left.d=(2 K t)^{1 / 2}\right)$. In principle, it is possible to evaluate the particle settling speed from the time lag between maximum fluxes intercepted by the $400 \mathrm{~m}$ traps compared to the $1000 \mathrm{~m}$ traps. Here it is made difficult by the flux patterns that are not very similar at $400 \mathrm{~m}$ and $1000 \mathrm{~m}$. However, at the beginning of spring, the rise of particle flux is recorded over the same time interval (of 8 days) at $400 \mathrm{~m}$ and
$1000 \mathrm{~m}$. It implies that most particles settles at a speed greater than $75 \mathrm{~m} \mathrm{~d}^{-1}$. Considering a settling velocity of $100 \mathrm{~m} \mathrm{~d}^{-1}$ [see, e.g., Newton et al., 1994; Waniek et al., 2000], a particle takes 4 days to reach $400 \mathrm{~m}$ and 10 days to reach $1000 \mathrm{~m}$. It follows that the radius of the statistical funnel is of the order of $26 \mathrm{~km}$ at $400 \mathrm{~m}$ and $42 \mathrm{~km}$ at $1000 \mathrm{~m}$. Therefore NE400 and NE1000 traps are clearly under the influence of A1 around February and August. At most, SW400 may have collected particles produced at the A2 rim during the spring period.

\subsubsection{Illustration of the Interannual Variability}

[50] The samples were collected in the POMME quadrangle for 1.5 years, allowing us to compare over 6 months the fluxes obtained in 2001 to those obtained in 2002. It has to be noted that for samples collected after February 2002, no ${ }^{230} \mathrm{Th}$ measurements were made so it is not possible to evaluate precisely the trapping efficiency. However, it was suggested from long sediment trap time series, that there is little interannual changes in the trapping efficiency [Scholten et al., 2001]. Therefore for each trap, we apply the trapping efficiency determined for the first year of collection to the following year. This may introduce an independent bias for each trap. However, these biases should tend to cancel if we average the flux over the POMME area. Therefore for each depth, we calculated the mean pattern of the mass flux for 2001 and for 2002. The difference of intensity and timing of the productive event in 2001 and 2002 are significant. The mass fluxes averaged over the whole POMME quadrangle at $400 \mathrm{~m}$ and at $1000 \mathrm{~m}$ for the period of February-June 2001 and 2002 are presented Figure 3.

[51] The maximum export event started later in 2002 than in 2001 as indicated in Table 2 and Figure 3. For the traps at $400 \mathrm{~m}$, the time lag is 30 days for the north sites but this time lag is not present at the SE site. The time lag is very clear for the traps at $1000 \mathrm{~m}$ that all indicate that the maximum export occurred 26 days later in 2002 compared to 2001. In addition to this important time difference, the intensity of the export was weaker in 2002 . At $400 \mathrm{~m}$, the ratio flux $2002 /$ flux $_{2001}$ for the period February-June ranged from $0.3(\mathrm{NW})$ to $0.8(\mathrm{NE})$ at $400 \mathrm{~m}$ and from $0.2(\mathrm{NW})$ to 0.7 (NE) at $1000 \mathrm{~m}$.

[52] The interannual variability depicted by these data was documented previously, in particular in the northeast Atlantic [Newton et al., 1994] and during the NABE-BOFS experiment the 1990/1989 ratio of mass flux during the major flux events was 0.55 . Waniek et al. [2005] recently pointed out that the strong interannual variability of the particle flux observed between 1994 and 2001 at station L1/ $\mathrm{K} 276$ is the result of the variability of phytoplankton biomass and primary production in the euphotic zone of the region.

[53] More precisely, such interannual variability can be strongly related to the differences observed in the mixed layer depth (MLD) and the time of the establishment of the summer stratification. According to Lévy et al. [2005b], on average over the POMME area, the MLD in 2001 was maximum at the beginning of March and the thermocline was established by mid-April whereas in 2002, the MLD was maximum about 1 month later, so that nutrients were brought later in the surface water, resulting in a later start of the bloom. Furthermore, the stratification was established 

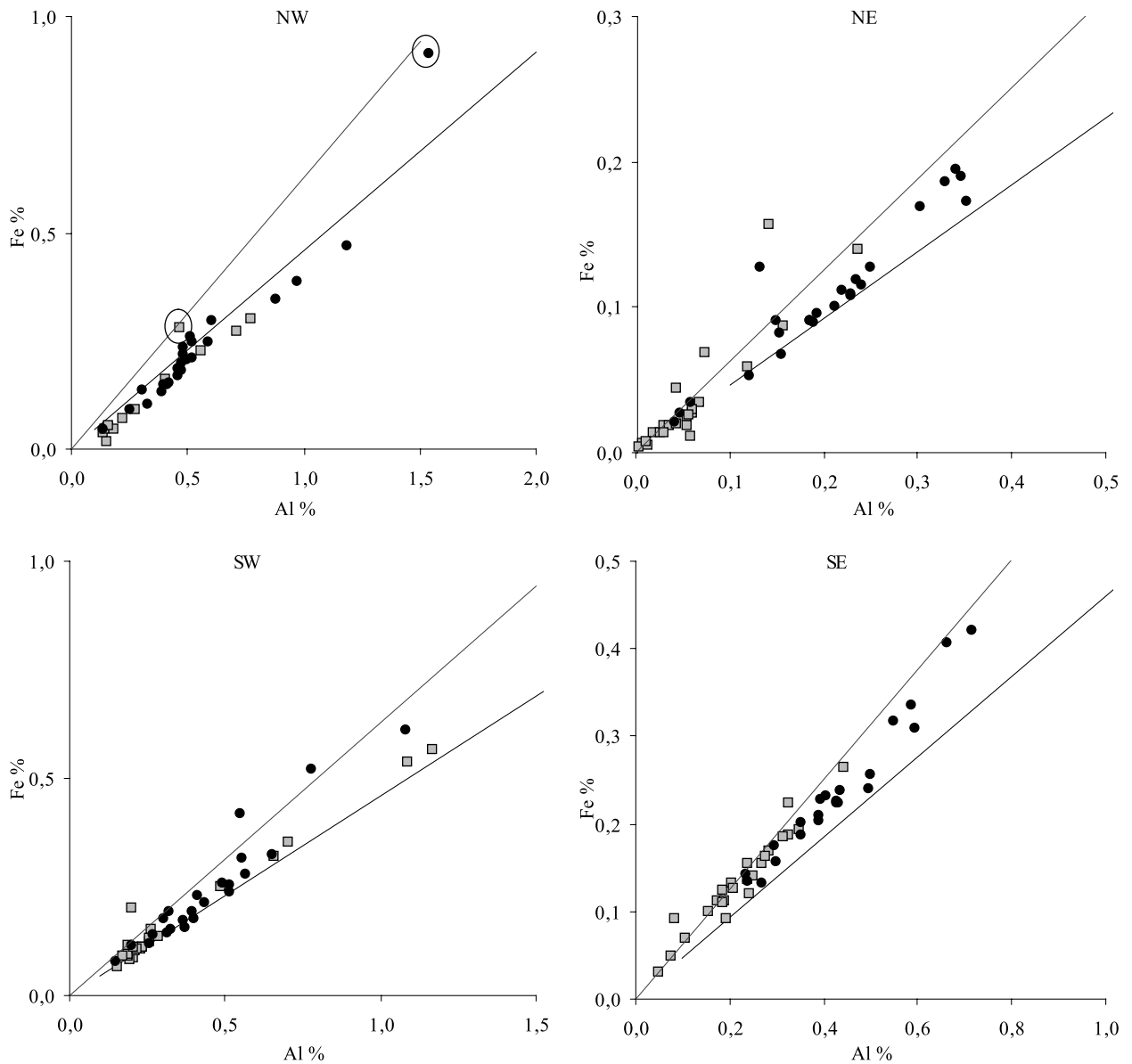

Figure 12. $\mathrm{Fe}=f(\mathrm{Al})$ for the trap samples collected from February 2001 to August 2001. The upper line represents the typical Saharan end-member ratio [Guieu et al., 2002a]; the lower line represents the ratio of the fine sediments deposited at the northern Portuguese shelf [Araujo et al., 2002].

later but the time lag was shorter allowing a faster use of the nutrients explaining the shorter duration of the export event.

[54] Smaller events, probably linked to wind events could have deepened the mixed layer for short periods of time during the summer, bringing new nutrients at the surface and allowing production and export. Calculation of the MLD in the vicinity of the traps (Y. Lehahn, personal communication, 2004) did indeed show that the MLD was suddenly deepened $(\sim 50 \mathrm{~m})$ around mid-April. This wind event effect on biological productivity was clearly shown during strong summer stratification in the Mediterranean Sea [Andersen and Prieur, 2000].

\subsection{Origin and Fluxes of the Lithogenic Particles}

[55] The Al flux increases significantly between $400 \mathrm{~m}$ and $1000 \mathrm{~m}$ at the NE, SE and SW sites (Figure 10). For the SW site, the uncertainty in the trapping efficiency is large, so that changes of fluxes with depth are poorly constrained. The increase of the corrected lithogenic flux between $500 \mathrm{~m}$ and $1000 \mathrm{~m}$ was observed in the NE Atlantic [Scholten et al., 2001]. Close to the shelf break, such increases of $\mathrm{Al}$ flux are produced by the inputs of nepheloid layers [Antia et al., 2001a, 2001b; McCave et al., 2001]. The presence of Meddies around $1000 \mathrm{~m}$ depth [see, e.g., Richardson et al., 1991] could also provide small lithogenic particles that can be aggregated to the large sinking particles. The role of scavenging dissolved $\mathrm{Al}$ onto the settling particles is assumed to be negligible. The $\mathrm{Al}$ fluxes measured at $1000 \mathrm{~m}$ in the POMME area compare well with results obtained on deep traps (3000$4000 \mathrm{~m}$ ) between $33^{\circ} \mathrm{N}$ and $47^{\circ} \mathrm{N}$ in the NE Atlantic indicating a reduced direct influence of the Saharan dust Plume compared to the tropical North Atlantic [Kuss and Kremling, 1999]. The A1/Fe ratio in the trapped material may provide information on the origin of this lithogenic material because the average $\mathrm{Fe} / \mathrm{Al}$ ratio of the fine sediments deposited at the northern Portuguese shelf $(\mathrm{Fe} / \mathrm{Al}=$ 0.46) [Araujo et al., 2002] is significantly different from the average aerosols from the Sahara $(\mathrm{Fe} / \mathrm{Al}=0.63)$ [Guieu et al., 2002a]. While a Saharan signature suggests an aeolian input of the particles, a signature close to the sediment shelf end-member implies that the lithogenic matter has been advected from the continental margins. The composition of the sinking lithogenic material compared to these end-members for $\mathrm{Al}$ and $\mathrm{Fe}$ concentrations are reported in Figure 12. The Fe/Al ratio is close to the sediment shelf one for the samples collected at the NW site, both at 400 and $1000 \mathrm{~m}$. It has to be noted that cup 1 at $400 \mathrm{~m}$ and $1000 \mathrm{~m}$ have a typical Saharan end-member 
ratio that may be attributed to Saharan particles carried during a strong Saharan event that took place in the area at mid-February [Mosseri et al., 2005]. At the NE and SW sites, the $\mathrm{Fe} / \mathrm{Al}$ ratio is intermediate between the shelf sediment and the Saharan end-members indicating a probable mixed origin of the particles. Samples from the SW site collected at $1000 \mathrm{~m}$ from late February to early March have a $\mathrm{Fe} / \mathrm{Al}$ ratio that indicates a Saharan origin of the lithogenic material, in agreement with the high ${ }^{232} \mathrm{Th}$ content and low ${ }^{230} \mathrm{Th} /{ }^{232} \mathrm{Th}$ ratio that allowed to identify a pulse of aeolian dust (Roy-Barman et al., submitted manuscript, 2005) in the same samples. For the SE site, the $\mathrm{Fe} / \mathrm{Al}$ ratio clearly indicates a Saharan origin of the lithogenic particles at $400 \mathrm{~m}$ and a mixed origin between shelf sediments and Saharan dust for the samples collected at $1000 \mathrm{~m}$. If the Saharan signature of the sample was due to transport of lithogenic particles by Mediterranean waters, this signature should be found only at $1000 \mathrm{~m}$ depth where the Mediterranean waters is typically found. This is not the case, so it is likely that the Saharan signature of the lithogenic material is dominated by direct atmospheric inputs [Sarthou and Jeandel, 2001; Guieu et al., 2002b] or due to the influence of east Atlantic surface waters that also receive substantial inputs from Sahara [Kramer et al., 2004].

\section{Conclusions}

[56] The strategy adopted to tackle the question concerning the role of the mesoscale activity on the export within the POMME quadrangle, was quite successful: at least two moorings (NE and to a lesser extend SW) were temporarily under the influence of anticyclonic eddies. High currents (up to $48 \mathrm{~cm} \mathrm{~s}^{-1}$ ) and temporary deepening recorded by the mooring indicate that the site NE was under the dynamical influence of the anticyclonic eddy A1 from February to 1 December. The dynamical influence of this eddy was mostly noticeable at $400 \mathrm{~m}$ but not negligible at $1000 \mathrm{~m}$. The POC flux reveals a much stronger POC export at NE 400 than at the other sites revealing a clear role of the A1 anticyclonic eddy that is associated with a deepening of the permanent thermocline but also with a shoaling of the seasonal thermocline and of the associated nutracline that produces a significant recharge of the photic zone with nitrate during the summer [Fernández et al., 2005a].

[57] Similarly, in the southwest of the POMME area, the core of the A2 anticyclonic eddy has a high nitrate level due to an uplift of the nitrate isolines. Carbon export at the SW site was among the highest recorded during spring 2001; at this time, the center of the A2 eddy was within $50 \mathrm{~km}$ of the SW trap. The higher export at $400 \mathrm{~m}$ in the northern part of the POMME zone compared to the southern part could be both due to the effect of mesoscale activity and related to the productivity gradient between the subtropical and the subpolar North Atlantic.

[58] A particular effort was made to analyze Th isotopes in order to properly constrain the particle flux. The ${ }^{230} \mathrm{Th}_{e x}$ flux intercepted by the traps were well below the production rate in the overlying water column due to the poor collection efficiency. We hypothesize that the collection efficiency was related to the mesoscale activity encountered during the POMME experiment as the data show that at $400 \mathrm{~m}$, the trapping efficiency decreases when the mean current speed increases. If we varied efficiency throughout the year, we might improve our calculated fluxes.

[59] The particle fluxes collected in the POMME zone are consistent with those collected in the NE Atlantic at similar latitude. There is a significant temporal and spatial variability of the particulate fluxes and we show that the interannual variability was strong between 2001 and 2002. This variability could be related to the differences observed in the mixed layer depth (MLD) and the time of the establishment of the summer stratification. Our observations are in very good agreement with work from Lévy et al. [2005b], that show important differences in the establishment of the MLD between the 2 years. The stratification seems to control the timing and the intensity of the spring export over the whole POMME zone.

[60] Finally, our data clearly indicate that mesoscale activity can temporarily affect the mass flux, the composition of the collected particles and POC export. However, the spatial variability of the POC export averaged for a year over the POMME quadrangle was only $32 \%$ at $1000 \mathrm{~m}$. The estimated export efficiency (organic $\mathrm{C}$ exported/amount of $\mathrm{C}$ produced in the surface layer) indicates that only $2 \%$ of the carbon produced in the surface is exported below $1000 \mathrm{~m}$ and represents only $4-15 \%$ of the new production. This implies that in the POMME area, most of the organic carbon export is not done by particle settling but rather by DOC transport through winter convection and mode water circulation.

[61] Acknowledgments. The authors wish to warmly thank L. Mémery and G. Reverdin, PIs of the POMME program, the captains and crews of the $\mathrm{R} / \mathrm{V}$ L'Atalante and R/V Thalassa, and the Chief Scientists of the cruises. The POMME program was supported by the French agencies CNRS (INSU (PROOF-PATOM)), IFREMER, Meteo-France, and SHOM. We thank J. Mosserie for the Si data, Y. Lehahn for its input in the discussion, and two anonymous reviewers for their helpful feedback and suggestions. We would also like to thank J. Adkins for his help with the English translation and for valuable feedback.

\section{References}

Andersen, V., and L. Prieur (2000), One-month study in the open NW Mediterranean Sea (DYNAPROC experiment, May 1995): Overview of hydrobiogeochemical structures and effects of wind events, Deep Sea Res., Part I, 47, 397-422.

Andersson, P. S., G. J. Wasserburg, J. H. Chen, D. A. Papanastassiou, and J. Ingri (1995), ${ }^{238} \mathrm{U}_{-}{ }^{234} \mathrm{U}$ and ${ }^{232} \mathrm{Th}-{ }^{230} \mathrm{Th}$ in the Baltic Sea and in river water, Earth Planet. Sci. Lett., 130, 217-234.

Antia, A. N., B. von Bodungen, and R. Peinert (1999), Particle flux across the mid-European continental margin, Deep Sea Res., Part I, 46, 1999-2024.

Antia, A. N., J. Maßßen, P. Herman, M. Voß, J. Scholten, S. Groom, and P. Miller (2001a), Spatial and temporal variability of particle flux at the N.W. European continental margin, Deep Sea Res., Part II, 48, $3083-3106$

Antia, A. N., et al. (2001b), Basin-wide particulate carbon flux in the Atlantic Ocean: Regional export patterns and potential for atmospheric $\mathrm{CO}_{2}$ sequestration, Global Biogeochem. Cycles, 15, 845-862.

Araujo, M. F., J.-M. Jouanneau, P. Valério, T. Barbosa, A. Gouveia, O. Weber, A. Olivereira, A. Rodrigues, and J. M. A. Dias (2002), Geochemical tracers of northern Portuguese estuarine sediments on the shelf, Prog. Oceanogr, 52, 277-297.

Bacon, M. P., and R. F. Anderson (1982), Distribution of thorium isotopes between dissolved and particulate forms in the deep sea, J. Geophys. Res., 87, 2045-2056.

Bacon, M. P., C.-A. Huh, A. P. Fleer, and W. G. Deuser (1985), Seasonality in the flux of natural radionuclides and plutonium in the deep Sargasso Sea, Deep Sea Res., Part I, 32, 273-286.

Baker, E. T., H. B. Milburn, and D. A. Tennant (1988), Field assessment of sediment trap efficiency under varying flow conditions, J. Mar. Res., 46, $573-592$. 
Banner, J. L., G. J. Wasserburg, J. H. Chen, and C. H. Moore (1990), U-234 U-238 TH-230 TH-232 systematics in saline groundwaters from central Missouri, Earth Planet. Sci. Lett., 101, 296-312.

Bishop, J. K. (1988), The barite-opal-organic carbon association in oceanic particulate matter, Nature, 332, 341-343.

Bory, A., et al. (2001), Downward particle fluxes within different productivity regimes off the Mauritanian upwelling zone (EUMELI program), Deep Sea Res., Part I, 48, 2251-2282.

Boyd, P., and P. Newton (1995), Evidence of the potential influence of phytoplanktonic community structure on the interannual variability of particulate organic carbon flux, Deep Sea Res., Part I, 46, 619-639.

Buesseler, K. O. (1991), Do upper-ocean sediment traps provide an accurate record of particle flux?, Nature, 353, 420-423.

Buesseler, K. O. (1998), The decoupling of production and particulate export in the surface ocean, Global Biogeochem. Cycles, 12, $297-$ 310

Cardinal, D., F. Dehairs, T. Cattaldo, and L. André (2001), Geochemistry of suspended particles in the Subantarctic and Polar Frontal Zones south of Australia: Constraints on export and advection processes, J. Geophys. Res., 106, 31,637-31,656.

Chase, Z., and R. F. Anderson (2004), Comment on "On the importance of opal, carbonate, and lithogenic clays in scavenging and fractionating ${ }^{230} \mathrm{Th},{ }^{231} \mathrm{~Pa}$ and ${ }^{10} \mathrm{Be}$ in the ocean" by $\mathrm{S}$. Luo and T.-L. Ku, Earth Planet. Sci. Lett., 220, 213-222.

Dehairs, F., D. Shopova, S. Ober, C. Veth, and L. Goeyens (1997), Particulate barium stocks and oxygen consumption in the Southern Ocean mesoplegaic water column during spring and early summer: Relationship with export production, Deep Sea Res., Part II, 44, 497-516.

Dehairs, F., N. Fagel, A. N. Antia, R. Peinert, M. Elskens, and L. Goeyens (2000), Export production in the Gulf of Biscay as estimated from bariumbarite in settling material: a comparison with new production, Deep Sea Res., Part I, 47, 583-601.

Eagle, M., A. Paytan, K. R. Arrigo, G. van Dijken, and R. W. Murray (2003), A comparison between excess barium and barite as indicators of carbon export, Paleoceanography, 18(1), 1021, doi:10.1029/ 2002PA000793.

Fagel, N., F. Dehairs, R. Peinert, A. Antia, and L. André (2004), Reconstructing export production at the NE Atlantic margin: Potential and limits of the Ba proxy, Mar. Geol., 24, 11-25.

Fernández, I. C. (2003), Cycle de l'azote et production primaire dans l'Atlantique Nord-Est: Suivi saisonnier et influence de la meso échelle, Ph.D. thesis, 331 pp., Univ. de la Méditerranée, Marseille, France.

Fernández, I. C., P. Raimbault, G. Caniaux, N. Garcia, and P. Rimmelin (2005a), Influence of mesoscale eddies on nitrate distribution during the POMME program in the north-east Atlantic Ocean, J. Mar. Syst., 55, $155-175$

Fernández, C. I., P. Raimbault, N. Garcia, P. Rimmelin, and G. Caniaux (2005b), An estimation of annual new production and carbon fluxes in the northeast Atlantic Ocean during 2001, J. Geophys. Res., 110, C07S13, doi:10.1029/2004JC002616.

Francois, R., S. Honjo, S. J. Manganini, and G. E. Ravizza (1995), Biogenic barium fluxes to the deep sea: Implications for paleoproductivity reconstruction, Global Biogeochem. Cycles, 9, 289-303.

Francois, R., S. Honjo, R. Krishfield, and S. Manganini (2002), Factors controlling the flux of organic carbon to the bathypelagic zone of the ocean, Global Biogeochem. Cycles, 16(4), 1087, doi:10.1029/ $2001 \mathrm{~GB} 001722$.

Gardner, W. D. (1980), Sediment trap dynamics and calibration: A laboratory evaluation, J. Mar. Res., 38, 17-39.

Geibert, W., and R. Usbeck (2004), The adsorption of thorium and protactinium on different particle types in dependence of the provenance of natural seawater, Geochim. Cosmochim. Acta, 68, 1489-1501.

Girardot, J. P. (2000), CALM, Conception Assistée des Lignes de Mouillages, LPO internal report, 31 pp., UFR Sci. et Techniques, Brest, France. Goutx, M., C. Guigue, N. Leblond, A. Desnues, A. Dufour, D. Aritio, and C. Guieu (2005), Particle flux in the northeast Atlantic Ocean during the POMME experiment (2001): Results from mass, carbon, nitrogen, and lipid biomarkers from the drifting sediment traps, J. Geophys. Res., doi: 10.1029/2004JC002749, in press.

Guieu, C., M.-D. Loÿe-Pilot, C. Ridame, and C. Thomas (2002a), Chemical characterization of the Saharan dust end-member: Some biological implications for the western Mediterranean Sea, J. Geophys. Res., 107(D15), 4258, doi:10.1029/2001JD000582.

Guieu, C., Y. Bozec, S. Blain, C. Ridame, G. Sarthou, and N. Leblond (2002b), Impact of high Saharan dust inputs on dissolved iron concentrations in the Mediterranean Sea, Geophys. Res. Lett., 29(19), 1911, doi:10.1029/2001GL014454.

Honjo, S., and S. J. Manganini (1993), Annual biogenic particle fluxes to the interior of the North Atlantic Ocean studied at $34^{\circ} \mathrm{N}, 21^{\circ} \mathrm{W}$ and $48^{\circ} \mathrm{N}$, $21^{\circ} \mathrm{W}$, Deep Sea Res., Part I, 40, 587-607.
Jeandel, C., K. Tachikawa, A. Bory, and F. Dehairs (2000), Biogenic barium in suspended and trapped material as a tracer of export production in the tropical north east Atlantic (EUMELI sites), Mar. Chem., 71, 125142.

Kähler, P., and E. Bauerfeind (2001), Organic particles in a shallow sediment trap: Substantial loss to the dissolved phase, Limnol. Oceanogr., 46, $719-723$.

Knauer, G., and V. Asper (1989), Sediment trap technology and sampling: Report of the U.S. GOFS Working Group on Sediment Trap Technology and Sampling, Plann. Rep. 10, 94 pp., Univ. of S. Miss., Woods Hole Oceanogr. Inst., Woods Hole, Mass.

Kramer, P., G. Laan, K. Sarthou, R. Timmermans, and H. J. W. de Baar (2004), Distribution of dissolved aluminum in the high atmospheric input region of the subtropical waters of the North Atlantic Ocean, Mar. Chem., $88,85-101$.

Kuss, J., and K. Kremling (1999), Particle trace element fluxes in the deep northeast Atlantic Ocean, Deep Sea Res., Part I, 46, 149-170.

Leblanc, K., A. Leynaert, I. C. Fernandez, P. Rimmelin, T. Moutin, P. Raimbault, J. Ras, and B. Quéguiner (2005), A seasonal study of diatom dynamics in the North Atlantic during the POMME experiment (2001): Evidence for Si limitation of the spring bloom, J. Geophys. Res., 110, C07S14, doi:10.1029/2004JC002621.

Le Cann, B., M. Assenbaum, J.-C. Gascard, and G. Reverdin (2005), Observed mean and mesoscale upper ocean circulation in the midlatitude northeast Atlantic, J. Geophys. Res., 110, C07S05, doi:10.1029/ 2004JC002768

Legeleux, F., and J.-L. Reyss (1996), ${ }^{228} \mathrm{Ra} /{ }^{226} \mathrm{Ra}$ activity ratio in oceanic settling particles: Implications regarding the used of barium as a proxy for paleo-productivity reconstruction, Deep Sea Res., Part I, 43, 18571863.

Lévy, M., P. Klein, and A.-M. Tréguier (2001), Impact of sub-mesoscale physics on production and subduction of phytoplankton in an oligotrophic régime, J. Mar. Syst., 59, 535-565.

Lévy, M., M. Gavart, L. Mémery, G. k Caniaux, and A. Paci (2005a), A four-dimensional mesoscale map of the spring bloom in the northeast Atlantic (POMME experiment): Results of a prognostic model, J. Geophys. Res., 110, C07S21, doi:10.1029/2004JC002588.

Lévy, M., Y. Lehahn, J.-M. André, L. Mémery, H. Loisel, and E. Heifetz (2005b), Production regimes in the northeast Atlantic: A study based on Sea-viewing Wide Field-of-view Sensor chlorophyll and ocean general circulation model mixed layer depth, J. Geophys. Res., 110, C07S10, doi:10.1029/2004JC002771.

Loecht, K., H. W. Ducklow, M. J. R. Fasham, and C. Stienens (1993), Plankton succession and carbon cycling at $47^{\circ} \mathrm{N}, 20^{\circ} \mathrm{W}$ during the JGOFS North Atlantic Bloom Experiment, Deep Sea Res., Part II, 40, $91-114$.

Luo, S., and T.-L. Ku (2004), On the importance of opal, carbonate, and lithogenic clays in scavenging and fractionating ${ }^{230} \mathrm{Th},{ }^{231} \mathrm{~Pa}$ and ${ }^{10} \mathrm{Be}$ in the ocean, Earth Planet. Sci. Lett., 220, 201-211.

Lutz, M., R. Dunbar, and K. Caldeira (2002), Regional variability in the vertical flux of particulate organic carbon in the ocean interior, Global Biogeochem. Cycles, 16(3), 1037, doi:10.1029/2000GB001383.

Mahadevan, A., and D. Archer (2000), Modeling the impact of fronts and mesoscale circulation on the nutrient supply and biogeochemistry of the upper ocean, J. Geophys. Res., 105, 1209-1225.

McCave, I. N., I. R. Hall, A. N. Antia, L. Chou, F. Dehairs, R. S. Lampitt, L. Thomsen, T. C. E. van Weering, and R. Wollast (2001), Distribution, composition and flux of particulate material over the European margin at $47^{\circ}-50^{\circ}$ N, Deep Sea Res., Part II, 48, 3107-3139.

McGillicuddy, D. J., Jr., A. R. Robinson, D. A. Siegel, H. W. Jannasch, R. Johnson, T. D. Dickey, J. McNeil, A. F. Michaels, and A. H. Knap (1998), Influence of mesoscale eddies on new production in the Sargasso Sea, Nature, 394, 263-266.

Mémery, L., G. Reverdin, J. Paillet, and A. Oschlies (2005), Introduction to the POMME special section: Thermocline ventilation and biogeochemical tracer distribution in the northeast Atlantic Ocean and impact of mesoscale dynamics, J. Geophys. Res., doi:10.1029/2005JC002976, in press.

Mortlock, R. A., and P. N. Froelich (1989), A simple method for the rapid determination of biogenic opal in pelagic marine sediments, Deep Sea Res., Part A, 36, 1415-1426.

Mosseri, J., B. Quéguiner, P. Rimmelin, N. Leblond, and C. Guieu (2005), Sea fluxes in the northeast Atlantic frontal zone of Mode Water formation $\left(38^{\circ}-45^{\circ} \mathrm{N}, 16^{\circ}-22^{\circ} \mathrm{W}\right)$ in $2001-2002, J$. Geophys. Res., 110, C07S19, doi: $10.1029 / 2004 J C 002615$

Murphy, J., and J. P. Riley (1962), A modified single solution method for the determination of phosphate in natural waters, Anal. Chim. Acta, 27, $31-36$.

Neuer, S., V. Ratmeyer, R. Davenport, G. Fischer, and G. Wefer (1997), Deep water particle flux in the Canary Island region: Seasonal trends in 
relation to long-term satellite derived pigment data and lateral sources, Deep Sea Res., Part I, 44, 1451-1466.

Newton, P. P., R. S. Lampitt, T. D. Jickells, P. King, and C. Boutle (1994) Temporal and spatial variability of biogenic particle fluxes during the JGOFS northeast Atlantic process studies at $47^{\circ} \mathrm{N}, 20^{\circ} \mathrm{W}$, Deep Sea Res., Part I, 41, 1617-1642.

Paillet, J., and M. Arhan (1996), Shallow pycnoclines and mode water subduction in the eastern North Atlantic, J. Phys. Oceanogr., 26, 96-114.

Paillet, J., B. Le Cann, X. Carton, Y. Morel, and A. Serpette (2002), Dynamics and evolution of a northern meddy, J. Phys. Oceanogr., 32, 5579.

Reverdin, G., M. Assenbaum, and L. Prieur (2005), Eastern North Atlantic Mode Waters during POMME (September 2000-2001), J. Geophys. Res., 110, C07S04, doi:10.1029/2004JC002613.

Richardson, P. L., M. S. McCartney, and C. Maillard (1991), A search for meddies in historical data, Dyn. Atmos. Oceans, 15, 241-265.

Roy-Barman, M., J. H. Chen, and G. J. Wasserburg (1996), ${ }^{230} \mathrm{Th}^{-232} \mathrm{Th}$ systematics in the central Pacific Ocean: The sources and the fates of thorium, Earth Planet. Sci. Lett., 139, 351-363.

Roy-Barman, M., L. Coppola, and M. Souhaut (2002), Thorium isotopes in the western Mediterranean Sea: An insight in the marine particle dynamics, Earth Planet. Sci. Lett., 196, 161-174.

Roy-Barman, M., R. El Hayek, I. Voege, M. Souhaut, N. Leblond, and C. Jeandel (2003), Constraining the seasonal particle flux in the eastern North Atlantic with thorium isotopes, Geophys. Res. Abstr., 5, abstract EAE03-A-03212.

Sarthou, G., and C. Jeandel (2001), Seasonal variations of iron concentrations in the Ligurian Sea and iron budget in the western Mediterranean Sea, Mar. Chem., 74, 115-129.

Scholten, J. C., J. Fietzke, S. Vogler, M. M. Rutgers van der Loeff, A. Mangini, W. Koeve, J. Waniek, P. Stoffers, A. Antia, and J. Kuss (2001), Trapping efficiencies of sediment traps from the deep eastern North Atlantic: The ${ }^{230}$ Th calibration, Deep Sea Res., Part II, 48, $2383-2408$

Taylor, S. R., and S. M. McLennan (1985), The Continental Crust: Its Composition and Evolution, 46 pp., Blackwell, Malden, Mass.

Turekian, K. K., and E. H. Tausch (1964), Ba in deep-sea sediments of the Atlantic Ocean, Nature, 201, 696-697.

Usbeck, R., R. Schlitzer, G. Fischer, and G. Wefer (2003), Particle fluxes in the ocean: Comparison of sediment trap data with results from inverse modeling, J. Mar. Syst., 39, 167-183. van Beek, P., R. Francois, M. Conte, J. Reyss, S. Honjo, and M. Charette (2004), ${ }^{228} \mathrm{Ra} /{ }^{226} \mathrm{Ra}$ activity ratio in suspended matter to track barite formation and transport in the water column, Eos Trans. AGU, 84(52), Ocean Sci. Meet. Suppl., Abstract OS31L-01.

Waniek, J., W. Koeve, and R. D. Prien (2000), Trajectories of sinking particles and the catchment areas above sediment traps in the northeast Atlantic, J. Mar Res, 58, 983-1006.

Waniek, J. J., D. E. Schulz-Bull, T. Blanz, R. D. Prien, A. Oschlies, and T. J. Müller (2005), Interannual variability of deep water particle flux in relation to production and lateral sources in the northeast Atlantic, Deep Sea Res., Part I, 52, 33-50.

Wedepohl, K. H. (1995), The composition of the continental crust, Geochim. Cosmochim. Acta, 59, 1217-1232.

Yu, E. F., R. Francois, M. Bacon, A. P. Fleer, S. J. Manganini, M. M. Rutgers van der Loeff, and V. Ittekott (2001), Trapping effciency of bottom-tethered sediment traps estimated from the intercepted fluxes of ${ }^{230} \mathrm{Th}$ and ${ }^{231} \mathrm{~Pa}$, Deep Sea Res., Part I, 48, 865-889.

C. Bournot, Institut National des Sciences de l'Univers/Centre National de la Recherche Scientifique Division Technique, Technopôle Brest-Iroise, F-29280 Plouzané, France. (claudie.bournot@ifremer.fr)

A. Dufour, C. Guieu, and N. Leblond, Laboratoire d'Océanographie de Villefranche, Centre National de la Recherche Scientifique, La Darse, BP 08, F-06238 Villefranche-sur-mer Cedex, France. (dufour@obs-vlfr.fr; guieu@obs-vlfr.fr; leblond@obs-vlfr.fr)

C. Jeandel and M. Souhaut, Laboratoire d'Etudes en Géophysique et Océanographie Spatiales, Centre National de la Recherche Scientifique/ Centre National d'Etudes Spatiales/Institut de Recherche pour le Développment/Université Paul Sabatier, Observatoire Midi-Pyrénées, 14, Ave E. Belin, F-31400 Toulouse, France. (catherine.jeandel@notos.cst.cnes.fr; marc. souhaut@notos.cst.cnes.fr)

B. Le Cann, Laboratoire de Physique des Océans, UMR 6523, Centre National de la Recherche Scientifique/Institut Français de Recherche pour l'Exploitation de la Mer/Université de Bretagne Occidentale, 6, avenue Le Gorgeu, Brest Cedex 3, France. (bernard.le-cann@univ-brest.fr)

M. Roy-Barman, Laboratoire des Sciences du Climat et de l'Environnement/Institut Pierre-Simon Laplace, Centre National de la Recherche Scientifique, F-91198 Gif-sur-Yvette Cedex, France. (roy-barman@ lsce.cnrs-gif.fr) 